\section{Increasing Salinity Tolerance of Crops}

Mashael Alqahtani ${ }^{1,3}$, Stuart J. Roy ${ }^{2}$ and Mark Tester ${ }^{1}$

${ }^{1}$ Division of Biological and Environmental

Sciences and Engineering (BESE), King

Abdullah University of Science and Technology

(KAUST), Thuwal, Saudi Arabia

${ }^{2}$ School of Agriculture, Food and Wine, The

University of Adelaide, Glen Osmond, SA,

Australia

${ }^{3}$ The Biology Department, College of Science,

Princess Nourah bint Abdulrahman University

(PNU), Riyadh, Saudi Arabia

\section{Article Outline}

Glossary

Definition of the Subject

Introduction

Effects of Salt Stress on Plant Growth

Variation in Plant Salinity Tolerance

Mechanisms of Salt Tolerance

Generation of Salt Tolerant Crops

Future Directions

Bibliography

\section{Glossary}

Genetically modified plant A plant that has been transformed by artificial means with single or multiple genes from another variety or species.

Ionic exclusion The ability to maintain low concentrations of toxic ions, such as sodium and chloride, in the plant shoot.

Ionic stress The stress imposed on a plant by the accumulation of salts to toxic concentrations in cells, particularly those of the shoot, leading to premature death.

Osmotic stress The stress imposed on a plant by the accumulation of high concentrations of salt around the root, which reduces plant growth.

Osmotic tolerance The ability of a plant to maintain growth under osmotic stress.

Saline soil Soils affected by excess accumulation of salts. Accumulation of sodium chloride $(\mathrm{NaCl})$ on agricultural land has a severe impact on crop yield.

Salt tolerant plant A plant with the ability to grow and set seed in saline environments without significant reductions in plant biomass or yield.

Selective breeding Where two plant species with desirable phenotypes are bred together in an attempt to produce an offspring with both traits.

Tissue tolerance The ability to withstand high concentrations of toxic ions in the shoot by compartmentalizing ions such as sodium, $\mathrm{Na}^{+}$, out of the cytoplasm (i.e., into the vacuole), and accumulating compatible solutes in the cytoplasm to balance osmotic potential.

\section{Definition of the Subject}

Plant growth and yield are severely affected by saline soils. High concentrations of salt in the soil make it difficult for plants to take up water, while the accumulated salts in cells, particularly the sodium $\left(\mathrm{Na}^{+}\right)$and chloride $\left(\mathrm{Cl}^{-}\right)$ions, are toxic to plant metabolism. These two factors result in a reduction in plant growth, an increase in the rate of leaf senescence, and a loss of crop yield. The fact that significant areas of farmland worldwide are affected by salt brings with it potentially serious implications for crop yield.

\section{Introduction}

Saline soils have been defined as areas where the electrical conductance (ECe; a means of measuring the concentration of ions in the soil) is greater than $4 \mathrm{dS} / \mathrm{m}$. It is at around $4 \mathrm{dS} / \mathrm{m}$ (approximately $40 \mathrm{mM} \mathrm{NaCl}$ ) that most plants start to exhibit 
significant reductions in yield [1]. Over 800 million hectares of land worldwide are affected by saline soils; this accounts for more than $6 \%$ of the total land area of the world [2]. Most of this saltaffected land has arisen from natural causes, such as the weathering of rocks, which releases a variety of soluble salts including $\mathrm{Cl}^{-}, \mathrm{Na}^{+}$, calcium, magnesium, sulfates, and carbonates [3]. Other sources of salt accumulation include the deposition of salts from seawater that is transported by wind and rain, as well as from salts carried in rainwater. It has been estimated that rainwater contains $6-50 \mathrm{mg} / \mathrm{kg}$ of sodium chloride $(\mathrm{NaCl})$, which, over time, can result in large-scale salt depositions [1].

In addition to the natural processes of salinization, farmland areas are affected by secondary types of salinity, which are a consequence of human activities such as land clearance and/or irrigation. This secondary form of salinity results in the raising of water tables and an increase in the concentration of salts around plant roots. Approximately 32 million hectares of the 1,500 million hectares farmed by dryland agriculture are affected by secondary salinity, while 45 million hectares of the 230 million hectares of irrigated land are salt affected [2]. Although it accounts for only $15 \%$ of the total cultivated area, irrigated land is twice as productive as dryland agriculture. Consequently, losses of yield which result from an increase in soil salinization in irrigated areas have a disproportionally large effect. Unfortunately, the areas of farmland affected by salinization are increasing and irrigated land is particularly at risk [1].

The deleterious effect of soil salinity on agricultural yields is enormous. To solve this problem will require a variety of approaches including altering farming practices to prevent soil salinization; the implementation of remediation schemes to remove salt from soils; and programs aimed at increasing the salt tolerance of crop plants, either through traditional breeding, genetic manipulation technologies, or domestication of halophytes, plants that by nature thrive in saline conditions. By increasing crop salinity tolerance, plant varieties can be generated which will grow on marginal saline soils while longer term land management practices are being introduced. However, before crop salinity tolerance can be improved, an understanding is required of the two separate stresses imposed on a plant when it is grown on a saline soil: osmotic stress and ionic stress.

\section{Effects of Salt Stress on Plant Growth}

\section{Osmotic Stress}

Osmotic stress affects a plant as the salt concentration around the root reaches approximately $4 \mathrm{dS} / \mathrm{m}$ and results in a rapid reduction in shoot growth [1, 4, 5, 162] (Fig. 1). Osmotic stress reduces the rate at which growing leaves expand, the rate of emergence of new leaves, and the development of lateral buds. As this stage of salt stress concerns the inability of a plant to maintain water relations, the cellular and metabolic processes involved are similar to those observed in drought-stressed plants [6]. This osmotic stress results in stomatal closure, increased leaf temperature, and inhibition of photosynthesis directly after salt exposure [163]. In dicotyledonous crop species, such as soybean, this stress leads to reductions in the size of leaves and the number of branches [1, 162], while in the monocotyledonous cereals, such as wheat, barley, and rice, the major effect is a reduction in leaf elongation, number of tillers, and therefore reduced total leaf area $[6,7,151]$.

Salinity stress can also affect root architecture, including primary root and/or lateral root growth $[176,177,178]$. The recovery of growth in the main and lateral roots is at least partially attributed to stress hormone abscisic acid ABA [200]. Moreover, it has been reported that salinity stress detrimentally affects the cell wall mechanical properties [173]. After exposure to salinity, the cell wall in the elongation zone of the root becomes softer, due to sodium ions replacing the load bearing boron and calcium ions that crosslink the individual cell wall components. The cell wall stiffness is restored due to the function of plasma membrane localized receptor kinase FERONIA that is proposed to function in concert with transient increases in cytosolic $\mathrm{Ca}^{2+}$ [173]. 

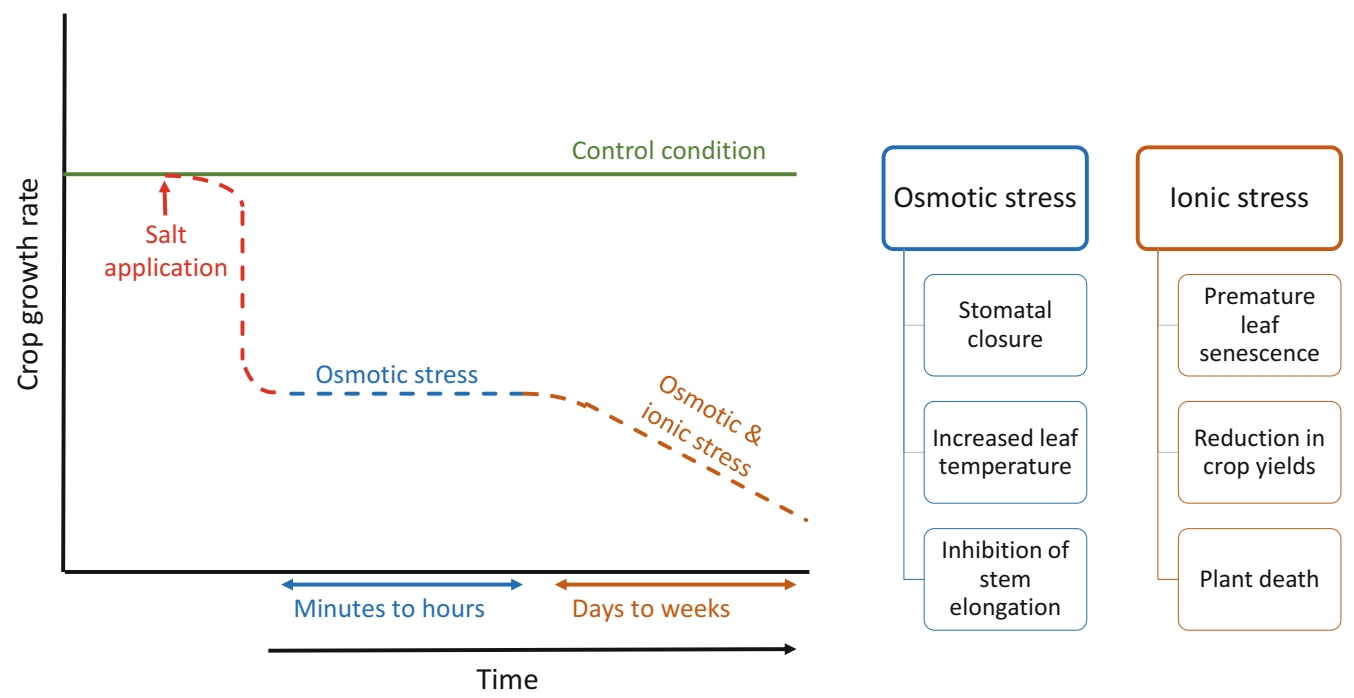

Adapted from Munns \& Tester (2008) Ann. Rev. Plant Biol. 59:651-681

Increasing Salinity Tolerance of Crops, Fig. 1 The effect of salt stress on the growth rate of a crop plant. Plants experience an immediate reduction in growth rate after exposure to salt as a result of osmotic stress. Overtime, the effect of ionic stress increases as shoot $\mathrm{Na}^{+}$

Although it is the roots that are initially exposed to the saline soil, it is the growth of the shoot which displays a greater sensitivity to salt; root growth recovers quickly even after exposure to relatively high levels of $\mathrm{NaCl}[4,8]$, different components of root system architecture, such as primary root or lateral roots recover at different rates and to different extent $[176,177]$, resulting in altered root architecture [161]. The reduction in leaf development has been attributed to the high salt concentration outside the roots and not to toxic levels of $\mathrm{Na}^{+}$or $\mathrm{Cl}^{-}$within the tissues of the plant $[9,10,11]$. This is supported by experiments where plants demonstrate reduced shoot growth when grown in a mixture of salts which individually are at concentrations below those necessary for ionic toxicity but together cause osmotic stress $[7,12]$. The mechanisms underlying this down regulation of leaf growth and shoot development remain unclear, but a decrease in shoot area is likely to reduce water use by the plant, thereby conserving soil moisture and preventing an increase in the soil salt concentration. It has been suggested that this reduction in growth concentrations build to toxic levels. The major symptoms of osmotic stress are closure of stomata, increase the leaf temperature and inhibition in stem elongation while in ionic stress are premature leaf senescence, reduced the crop yields and finally plant death (Adapted from [1])

rate is regulated by long distance signals in the form of plant hormones and, as the reduction in growth rate is independent of carbohydrate or water supply, is not due to nutrient deficiency $[13,14]$. It is not just vegetative growth that can be affected by osmotic stress, however, but also the reproductive development of a crop plant osmotically stressed plants have been found to exhibit either early flowering and/or a reduced number of flowers [1].

Osmotic stress has other detrimental effects on crop plants. On the surfaces of their leaves, plants have stomatal pores, tiny holes through which carbon dioxide $\left(\mathrm{CO}_{2}\right)$ enters the leaf, for use in photosynthesis and carbohydrate production, and through which water and oxygen leave the plant. Due to reduced water uptake, osmotically stressed plants close these stomatal pores $[1,15]$. The consequent reduction in $\mathrm{CO}_{2}$ assimilation results in a reduction of carbohydrate production which is detrimental to crop yield. Many plants are able to compensate partially for the reduction in the amount of $\mathrm{CO}_{2}$ entering the leaf by producing smaller, thicker leaves with more densely packed 
chloroplasts although this is expensive in terms of expenditure of energy [1]. The decrease in photosynthesis caused by the closure of stomatal pores has the secondary effect, a build-up of reactive oxygen species (ROS) [16, 17]. Reactive oxygen species are high energy forms of oxygen, such as superoxide and hydrogen peroxide, which can damage plant DNA and proteins. These ROS accumulate in plant leaves when the energy absorbed from sunlight by chloroplasts cannot be used to synthesize carbohydrates as there is insufficient $\mathrm{CO}_{2}$ in the leaf to provide the carbon source. If left unchecked, these ROS can cause significant damage to plants, so cells must produce a range of enzymes, such as superoxide dismutase (SOD), ascorbate peroxidase (APX), and catalase (CAT), to detoxify and convert the ROS into harmless forms $[16,17]$. These detoxifying enzymes are naturally present in plants to protect leaves from sudden bursts of sunlight, such as that which occurs when the sun emerges from behind a cloud, but more must be manufactured in response to salt stress, this again being an energy expensive process.

\section{Ionic Stress}

Ionic stress has a slower speed of onset than osmotic stress (Fig. 1). It occurs when the $\mathrm{Na}^{+}$or $\mathrm{Cl}^{-}$accumulation in older leaves reaches a high concentration, which results in premature leaf senescence [1, 4, 6, 18, 162]. All salts at high concentrations can affect plant growth, but in saline soils it is the $\mathrm{Na}^{+}$and $\mathrm{Cl}^{-}$ions which cause the most detrimental effects on growth. For some plant species, especially citrus, soybean, and grapevines, it is the accumulation of $\mathrm{Cl}^{-}$ions in the shoot that leads to toxicity, as $\mathrm{Na}^{+}$is retained within the roots and the stem [18-22]. The proteins that are involved in facilitating long distance transport of $\mathrm{Cl}^{-}$, which enhance $\mathrm{Cl}^{-}$exclusion and therefore salinity tolerance, have been described recently [174]. However, for most crop plants, including the cereals, $\mathrm{Na}^{+}$reaches toxic concentrations before $\mathrm{Cl}^{-}$and is the ion responsible for most of the damage caused to plants [1].

$\mathrm{Na}^{+}$and $\mathrm{Cl}^{-}$are delivered to the shoot in the transpiration stream, that is, in the water, which is being transported from the root to the shoot in the xylem of the plant. For most plants, the movement of $\mathrm{Na}^{+}$and $\mathrm{Cl}^{-}$back from the shoot to the roots via the phloem is relatively small, so most of the salt delivered to the shoot remains there [1, 18]. High concentrations of $\mathrm{Na}^{+}$in the shoot can cause a range of metabolic and osmotic problems for plants $[1,23]$. The metabolic toxicity of $\mathrm{Na}^{+}$is largely as a result of its ability to compete with $\mathrm{K}^{+}$, which is required for many essential cellular functions. Over 50 essential enzymes have been shown to be activated by $\mathrm{K}^{+}$. Consequently, high levels of cellular $\mathrm{Na}^{+}$, which will increase the cellular $\mathrm{Na}^{+}: \mathrm{K}^{+}$ratio and decrease the availability of $\mathrm{K}^{+}$, can disrupt a variety of enzymatic processes [24]. In addition, protein synthesis requires high concentrations of $\mathrm{K}^{+}$so that tRNA can bind to ribosomes [25]. A reduction in the amount of available cellular $\mathrm{K}^{+}$due to high concentrations of $\mathrm{Na}^{+}$will disrupt protein synthesis [26]. As older leaves have ceased expanding, they cannot use additional water to dilute the salt being transported into them, and this leads to an increase in the senescence of older leaves [162]. Consequently, a failure to exclude $\mathrm{Na}^{+}$from the shoot over time will result in the accumulation of toxic levels of ions leading to premature senescence and leaf death $[4,27]$. If the rate of leaf death is greater than leaf production, the photosynthetic capacity of the plant will be reduced, the plant will be unable to supply carbohydrates to any new leaves, and the growth rate of the plant will decrease.

There is also an osmotic component to ionic stress. During ionic stress, $\mathrm{Na}^{+}$and/or $\mathrm{Cl}^{-}$remain when water from the transpiration stream evaporates and can, therefore, accumulate to high concentrations in the leaf apoplast $[5,28] . \mathrm{Na}^{+}$ present in the apoplast interferes with ionic bridges between cell wall molecules, resulting in compromised cell wall stiffness that limits normal cell growth and reduces the cell wall's ability to withstand turgor pressure. In addition, high extracellular concentrations of ions will result in water leaving cells with a consequent severe impact on cellular function. High concentrations of $\mathrm{Na}^{+}$and $\mathrm{Cl}^{-}$in the leaf also present another osmotic problem, that of maintaining cellular water potential below that of the soil, thereby facilitating water 
uptake for growth. Under conditions of elevated salt concentrations in the soil, plants need to accumulate solutes in order to maintain water uptake. Under such circumstances, the most readily available and energy efficient solutes are the $\mathrm{Na}^{+}$and $\mathrm{Cl}^{-}$ions; however, high cellular concentrations of these ions are toxic. Although $\mathrm{Na}^{+}$and $\mathrm{Cl}^{-}$can be stored within the vacuole of a cell or in the apoplastic space, plant cells have difficulty in maintaining low cytosolic $\mathrm{Na}^{+}$and $\mathrm{Cl}^{-}$ [29-31]. Therefore, in order to reduce the water potential within the cell, plants need to synthesize solutes, which can be accumulated at high concentrations in the cytoplasm of cells without interfering with metabolism $[32,33]$. The synthesis of such compatible solutes, however, is energetically expensive and can make significant demands on the energy resources of a plant.

Overall, in comparison with nonstressed plants, salt stressed plants grow more slowly and die more rapidly. It has been estimated that, due to its immediate effect on plant growth, the osmotic stress has a greater impact than ionic stress on the growth rate of a crop [1, 162]. Ionic stress affects plants only at a later stage and has a lesser effect than osmotic stress, particularly at moderate salinity levels. Only when salt levels are high or if a plant is extremely salt sensitive will the ionic effect be greater than the osmotic.

\section{Variation in Plant Salinity Tolerance}

Plants vary widely in their response to saline soils. Many show reduced rates of growth and yield, while others, such as the salt tolerant saltbush (Atriplex amnicola), only reach an optimal growth rate when a moderate level of salt is present [1, 34]. Depending on their sensitivity to saline soils, plants can be divided into two groups: the salt sensitive glycophytes, which are relatively easily damaged by salt; and the salt tolerant halophytes which can tolerate, and may even require, high concentrations of salt in the soil. Indeed, the halophytic saltbush has been shown to survive at concentrations of salt similar or higher than that of seawater [34]. It has been estimated that only $2 \%$ of plant species are true halophytes, while the majority of species, including most crops, are glycophytes [35]. Within the monocotyledonous cereals, rice (Oryza sativa) is one of the most salt sensitive [36-39] and shows a significant decrease in growth and yield when exposed to moderate levels of $\mathrm{NaCl}$. By contrast, barley (Hordeum vulgare) is significantly more salt tolerant [1, 40]. While not as tolerant as barley, the hexaploid bread wheat (Triticum aestivum), which contains the genomes of three different wheat species (AABBDD), is moderately salt tolerant and is able to exclude $97-99 \%$ of $\mathrm{Na}^{+}$entering the shoot. The tetraploid durum wheat (T. turgidum ssp durum), which has the genomes of two species (AABB), is more salt sensitive than bread wheat as it lacks genes for salinity tolerance found on the bread wheat $\mathrm{D}$ genome and can exclude only $94-95 \%$ of the $\mathrm{Na}^{+}$entering the root $[6,30]$. In durum wheat, there is a clear deleterious relationship between the amount of $\mathrm{Na}^{+}$that accumulates in its shoot and the yield of the plant: the higher the $\mathrm{Na}^{+}$concentration, the lower the yield [41].

The variation in salinity tolerance of dicotyledonous crop species is even greater than that observed in the cereals. On a scale of salt sensitivity, sugar beet has been reported as salt tolerant, cotton and tomatoes intermediate in tolerance, and chickpea, beans, and soybean as sensitive to salt $[42,43]$. Quinoa, which is considered as a potential new crop, exhibits high salinity tolerance [164]. It has been shown that some varieties of Chenopodium quinoa grow better in $300 \mathrm{mM}$ of $\mathrm{NaCl}$ compared to $0 \mathrm{mM} \mathrm{NaCl}$ although there was no significant in the accumulation of $\mathrm{Na}^{+}$in their roots or shoots [164]. Many fruit trees, such as citrus, are classified as very salt sensitive [43], due to their inability to exclude $\mathrm{Cl}^{-}$from their transpiration stream. A number of legumes have been shown to be extremely salt sensitive, even more so than rice; others, such as alfalfa (Medicago sativa), are more salt tolerant than barley [1]. In addition to this variation in salinity tolerance between different crop species, variation also exists within species, some varieties, and lines having significantly greater salinity tolerance than others [40-44]. 


\section{Mechanisms of Salt Tolerance}

\section{Osmotic Tolerance}

Osmotic tolerance refers to the ability of plants to maintain plant growth and water uptake after an increase in $\mathrm{Na}^{+}$accumulation around the root. Osmotic stress rapidly reduces the expansion rates of shoots and roots. It also results in the closure of stomatal pores. Plants that are more tolerant to osmotic stress exhibit rapid growth recovery accompanied by a relatively small reduction in transpiration rate [168] and photosynthetic activity [163]. This would be desirable in irrigated farmland where water is not limiting but may be problematic in dryland agricultural systems if the soil water content is depleted before the end of the growing season.

Although it was thought that considerable variation for osmotic tolerance may exist within crop species, until recently this was not easily measured. The estimation of growth rates requires daily measurements of leaf growth or measurements of stomatal conductance [7, 41, 45, 46, 47]. These methods are usually either time consuming or have required destructive measurements of plant material to ensure accuracy. Nondestructive measurements have dramatically advanced our understanding of salt stress physiology. Digital images taken of the plants throughout time are currently allowing measurements of the plant relative growth rate immediately after exposure to salinity and, hence, measure osmotic tolerance. Variations in osmotic tolerance, based on the relative plant growth rate, have now been observed in rice [168], barley [181], durum wheat $[45,49]$, bread wheat [189], and in wild relatives of wheat, such as T. monococcum which is a modern day variety of the plant which donated the A genome to both durum and bread wheat [48].

Application of new imaging techniques, including infrared, fluorescence, and hyperspectral imaging, is now being applied in highthroughput phenotyping setups. Those advanced imaging technologies can be used to estimate plant growth and the effects of salinity on this parameter [48, 151], but also stomatal conductance [49], photosynthetic efficiency [163], and levels of carotenoids [165]. In the future, new ways of analyzing and modeling the data, such as the development of algorithms for tracking individual leaves through time, will allow even more in-depth phenotyping of plants using current and future imaging technologies. The combination of new technologies and new analysis tools will help scientists research other salinity tolerance mechanisms which are currently beyond our ability to characterize. Further genetic studies will reveal new genetic components and processes contributing to osmotic tolerance present among the wild relatives of our elite crop cultivars.

\section{Ionic Tolerance}

$\mathrm{Na}^{+}$can accumulate in the shoots of plants to reach toxic levels at concentrations that are below those required of $\mathrm{Cl}^{-}$for toxicity. Consequently, most studies have focused on revealing any variation in shoot $\mathrm{Na}^{+}$accumulation and on the transport of $\mathrm{Na}^{+}$within the plant. Ion concentrations in specific tissues can easily be measured at a specific developmental age, and either image analysis $[48,151]$ or a meter that measures chlorophyll content can be used to measure leaf senescence.

\section{Ionic Tolerance: Exclusion}

A long-established mechanism for salinity tolerance in crop plants is the exclusion of ions, particularly $\mathrm{Na}^{+}$, from the shoot. Due to the ease of experimentation, this is the mechanism perhaps most studied. A strong correlation between salt exclusion and salt tolerance has been shown for many crops, such as in durum wheat $[41,50]$, rice [51, 52], barley [40, 53, 54], lotus [55], and Medicago [56]. $\mathrm{Na}^{+}$and $\mathrm{Cl}^{-}$enter a plant initially from the soil through the root and are then rapidly transported to the shoot in the water of the transpiration stream. Roots are able to maintain relatively constant levels of $\mathrm{NaCl}$ by exporting excess salt either back to the soil or to the shoot. As a result, there is a higher accumulation of $\mathrm{Na}^{+}$and $\mathrm{Cl}^{-}$in the shoot compared with the root. If the net delivery of $\mathrm{Na}^{+}$and/or $\mathrm{Cl}^{-}$to the shoot could be reduced, this may enable a plant to become more salt tolerant. There are four distinct components that can be modified in order to reduce shoot $\mathrm{Na}^{+}$ 
and $\mathrm{Cl}^{-}$concentrations, all of which occur in the root: reduction in the initial influx of ions from the soil into the root; maximization of the efflux of ions from the roots back to the soil; reduction of the efflux of ions from the inner root cells into the xylem cells which are carrying water and ions to the shoot in the transpiration stream; and maximization of ion retrieval from the transpiration stream into root cells thereby retaining $\mathrm{Na}^{+}$and $\mathrm{Cl}^{-}$in the root. Many of the proteins that are involved in facilitating long distance transport of both $\mathrm{Na}^{+}$and $\mathrm{Cl}^{-}$are now known [96, 174]. Manipulation of these proteins could enhance $\mathrm{Na}^{+}$and/or $\mathrm{Cl}^{-}$exclusion and therefore salinity tolerance.

\section{Ionic Tolerance: Tissue Tolerance}

Tissue tolerance is the plant's ability to maintain tissue function while accumulating high levels of internal $\mathrm{Na}^{+}$or $\mathrm{Cl}^{-}$ions $[151,152]$. Tolerance requires the toxic ions to be compartmentalized into areas where they can do no damage. At the cellular level, this usually involves avoiding the accumulation of $\mathrm{Na}^{+}$and $\mathrm{Cl}^{-}$in the cytoplasm of the plant cell where most important metabolic processes occur. One strategy of tissue tolerance involves compartmentalization of ions within the vacuole, a large plant cell organelle, which can be used as a storage structure. Employing such a mechanism will allow a plant to accumulate high concentrations of $\mathrm{Na}^{+}$and $\mathrm{Cl}^{-}$within the shoot, while avoiding the toxicity effects. There already exists a large body of evidence for variation between different varieties of crops in terms of the rates of accumulation of shoot $\mathrm{Na}^{+}$and $\mathrm{Cl}^{-}$, as well as for the concentrations of these ions, which the different varieties can tolerate [152].

\section{Generation of Salt Tolerant Crops}

Salt tolerant crop plants may be generated once there is a clear understanding of the mechanisms underlying salinity tolerance and of the variation between plant species in effecting such mechanisms. Once identified, the benefit of introducing these salinity tolerance mechanisms into crops must be considered. For example, there would be a little point in introducing into a cereal the salinity tolerance mechanisms from a slow growing highly tolerant halophyte if that mechanism involved a slow growth phenotype which would result in the cereal taking years to reach maturity. In addition, a salt tolerant crop plant must do as well as a sensitive plant when grown in the absence of salt. A high yielding salt sensitive crop which shows a 50\% yield reduction under salt stress will still be of greater value to a farmer than a salt tolerant variety which displays little reduction in yield but which produces only $40 \%$ as much grain as the salt stressed sensitive variety in the first place.

Crop plants developed to have increased tolerance to both ionic and osmotic stresses would be able to grow at productive rates throughout the life cycle, and the severe losses of yield experienced for most crops growing on saline soils would be reduced. It should also be noted that it might be necessary to develop crop plants with a range of different salinity tolerance mechanisms depending on the environment in which the plants will grow. Crops grown by dryland agriculture may benefit particularly from possessing tissue tolerance mechanisms, as the accumulation of high concentrations of ions within the vacuoles of the plant cells may assist the plant in obtaining more water from the soil. By contrast, an osmotic tolerance strategy, combined with $\mathrm{Na}^{+}$exclusion, may be more beneficial to crops grown under irrigation so that water availability is not an issue, but the $\mathrm{Na}^{+}$content in that water may be high. It has been observed that the most salinity tolerant Australian barley have multiple mechanisms for tolerance [181].

Two approaches may be taken to improve the salt stress tolerance of current crops: the exploitation of natural variation in salinity tolerance between different varieties and species of crops; or the molecular breeding technologies to increase salinity tolerance. Both approaches have advantages and disadvantages as discussed below.

\section{Exploitation of Natural Variation}

For many crop species, there exists large natural variation in salinity tolerance mechanisms, with some lines and varieties producing significant 
yields under salt stressed environments. The screening of 5,000 accessions of bread wheat led to the identification of 29 accessions which produced seed when grown in $50 \%$ seawater [57], while screening of 400 Iranian wheat accessions identified several accessions with high grain yield under both salt stressed and control environments [58]. Varietal differences in yield in saline conditions have been observed in many crops such as durum wheat $[41,45,59,182,183]$, barley [60, 61, 153], soybean [62], citrus [19, 63], chickpea $[42,64]$, and rice $[65,66,185]$. The selection and breeding of these salt tolerant varieties with the current elite varieties grown by farmers would be a step forward in the generation of salt tolerant plants.

The selective breeding of lines with desirable salt tolerance traits with those lines possessing desirable traits for yield is an approach for generating salinity tolerant crops that has been practiced for thousands of years. One limitation with this approach is the time and space necessary to grow offspring from these crosses, test their salinity tolerance, obtain viable seed, and then repeat the crossing with a parent to produce the next generation. To overcome this limitation, there are molecular technologies that have been developed to add value to those approaches. Different varieties and species have different DNA sequences. The difference between the DNA may be subtle, such as between varieties of the same species where there may be a single nucleotide change in the coding sequence of a gene, or the differences can be extreme, such as the gene duplications or deletions observed between species. Modern molecular techniques enable the detection of these differences between individuals, varieties, and species and allow the design of molecular markers, which recognize specific differences in the DNA between two individuals. Using these molecular markers as DNA landmarks, it is possible to produce a map of plant chromosomes, which can be divided into regions. By finding differences in regions of DNA between two varieties of plants and then observing the phenotype of the offspring produced by breeding the two original varieties, it is possible to identify regions in DNA linked to that phenotype. These regions are often called quantitative trait loci (QTL). By identifying two different plant varieties with differences in salinity tolerance and by observing molecular markers that are different between the two parents, it is possible to identify QTL linked to salinity tolerance by screening their offspring. As salt tolerance is a complex trait, both genetically and physiologically, it is not uncommon to observe several QTL associated with tolerance.

QTL have now been identified for salinity tolerance in a number of plant species including barley [67, 68, 153, 208-210, 214], tomato [69], rice $[70,168,180]$, citrus [63], bread wheat [30, $71,182,189,201-207]$, and durum wheat [41, 73, 211-213]. When QTL have been discovered, one approach is to then identify the gene in that region of DNA, which is responsible for the salt tolerance phenotype. The SKC1 QTL identified on chromosome 1 in rice and the Naxl and Nax2 loci observed in durum wheat on chromosomes $2 \mathrm{~A}$ and $5 \mathrm{~A}$, respectively, have been narrowed down to genes belonging to a family of $\mathrm{Na}^{+}$transporters $[70,72,73]$, which have been shown previously to be important for exclusion of $\mathrm{Na}^{+}$from the shoot [74-79]. Once a QTL has been discovered, the plant that contains an important piece of DNA for salt tolerance can be bred with salt sensitive varieties to introduce into them the salt tolerant phenotype. As a molecular marker will be linked to the QTL, it is not necessary to screen every offspring produced from this cross with a salt sensitivity assay, rather, it is possible to identify which of the offspring have the piece of DNA important for salt tolerance by screening for the molecular marker linked to the salt tolerance QTL. While this does not necessarily speed up the length of time it takes an individual plant to reach maturity, it does reduce the necessity to screen hundreds of plants in saline conditions looking for those that are salt tolerant, so that more focus can be placed on breeding tolerance traits into crops.

While one approach is to identify a variety of a crop with good salt tolerance and then cross it to other members of that species, a second approach is to introduce salt tolerance traits from related species or near-wild relatives. 
Bread wheat and durum wheat are two separate plant species, but because of their genetic background there is the possibility of breeding these two species together to exchange valuable traits. Durum wheat is a tetraploid (AABB) containing two genomes from an ancient ancestral cross, the A genome and the $\mathrm{B}$ genome. Bread wheat is a hexaploid (AABBDD), with the same $\mathrm{A}$ and $\mathrm{B}$ genomes as durum wheat and also a third genome, the D genome [80]. It is possible to breed a bread wheat and durum wheat together to produce a pentaploid hybrid offspring, which has an AABBD genome. During sexual reproduction, there is the possibility of the chromosomes from the different wheat backgrounds to swap DNA, a process called recombination, thereby transferring genes from bread wheat to durum wheat and vice versa. Importantly, however, only chromosomes from the same genome can recombine, i.e., durum genome $\mathrm{A}$ with bread genome $\mathrm{A}$ and not durum genome $\mathrm{A}$ with bread genome B. By crossing this offspring with either bread wheat or durum wheat, it is possible to re-obtain tetraploid durum wheat and hexaploid bread wheat, only now containing genes from the other species. This has been done successfully to transfer disease resistance genes [80] and could be used for transferring salt resistance traits between the two species. Although difficult, because durum wheat contains no $\mathrm{D}$ genome, it is possible to introduce genes from the bread wheat D genome into durum wheat; however, a special wheat plant, with a mutation that affects the way in which chromosomes align in recombination, is required [81]. This technique was used to transfer the $\mathrm{K}^{+} / \mathrm{Na}^{+}$discrimination locus Knal from chromosome $4 \mathrm{D}$ of bread wheat to chromosome $4 \mathrm{~B}$ of durum wheat [82]. This new durum wheat line was able to maintain a high $\mathrm{K}^{+} / \mathrm{Na}^{+}$ratio in the leaves [82, 83], thereby increasing its salinity tolerance. However, there was no significant difference in grain yield between durum plants with the bread wheat Knal and those without, perhaps due to a yield penalty imposed by having a large section of the bread wheat $\mathrm{D}$ genome in durum wheat. Unfortunately, no agronomically acceptable durum variety containing the bread wheat Knal locus has been released [80].
In addition to looking for variation in plant salt tolerance in current cultivars, there is the possibility of introducing salinity tolerance traits to crop from their near-wild relatives. These species may have been evolving in areas of high salinity, away from the selective pressures inflicted on domesticated crops. It is, therefore, likely these relatives have developed novel salt tolerance mechanisms which might be introduced into current crops. This approach is not new and there have been many attempts to introduce genes from salt tolerant wild relatives to current salt sensitive crops. Traits for salt tolerance have been discovered in wild relatives of tomato, [84], potato [85], rice [44], wheat [80, 86-88], and barley [40, 86, 153], and several attempts have been made to introduce them to cultivated crops. Screening of eight wild Hordeum species, wild relatives of domesticated barley, revealed that seven of the eight had better $\mathrm{Na}^{+}$and $\mathrm{Cl}^{-}$exclusion than domesticated barley under a variety of salt stressed environments. A number of these relatives, such as $H$. spontaneum, H. marinum, and $H$. intercedens, had significantly higher relative growth rates than domesticated barley when grown under high salinity stress $[40,89]$.

T. urartu (AA) is the modern-day ancestor of the species that gave rise to the A genomes of durum and bread wheat. Both T. urartu and other closely related A genome species, such as T. monococcum spp. monococcum and T. monococcum spp. aegilopoides, show greater $\mathrm{Na}^{+}$exclusion than durum wheat $[80,90]$. Lines of $T$. monococcum also show great variation in both osmotic and $\mathrm{Na}^{+}$tissue tolerance [48] and are, therefore, a potential source of novel genes for salinity tolerance. It is possible to cross these species with durum wheat and transfer salinity tolerance traits. One success story of breeding a salinity tolerant crop has been the introduction of a $\mathrm{Na}^{+}$exclusion trait into durum wheat from a near-wild relative T. monococcum. Screening of multiple durum wheat lines for $\mathrm{Na}^{+}$exclusion from the shoot identified a durum landrace, line 149 , with significantly lower shoot $\mathrm{Na}^{+}$than cultivated durum [59]. It was discovered that $\mathrm{Na}^{+}$ exclusion in these lines was controlled by two major genes, Nax1 and Nax2, which had been 
introduced into durum from a cross with T. monococcum [91]. These two genes have been introduced separately into the Australian durum wheat Tamaroi with saline field trails demonstrating the presence of Nax2 reduces the $\mathrm{Na}^{+}$shoot accumulation and increases the grain yield of durum wheat by $25 \%$ [154]. However, there is no yield penalty from the Naxl locus but this genetic information can be used for improving salt tolerance in bread wheat [155].

Another wild relative source for wheat is from Aegilops tauschii, which is the modern-day version of the species that donated the $\mathrm{D}$ genome to bread wheat - there appears to be no modern-day equivalent of the B genome [80]. Several screens of Ae. tauschii have identified lines with lower shoot $\mathrm{Na}^{+}$accumulation and enhanced $\mathrm{K}^{+} / \mathrm{Na}^{+}$ discrimination than durum wheat, although the phenotype was comparable to bread wheat [29, $71,92]$. As the natural environment of Ae. tauschii is dry and moderately saline [80], there exists the possibility of introducing novel salinity tolerant genes into wheat. One possibility is the re-creation of the original cross that generated bread wheat by breeding durum wheat (AABB) with Ae. tauschii (DD), thereby creating a synthetic wheat (AABBDD) with a genome similar in style to bread wheat. While the technique is tricky, it has been successful in the past [92]. The advantage of this technique is that the $\mathrm{Na}^{+}$exclusion locus found on the $\mathrm{D}$ genome is introduced which is not on the A or B genomes of wheat. Synthetic hexaploid lines with enhanced $\mathrm{Na}^{+}$exclusion have been created successfully to have $\mathrm{Na}^{+}$exclusion similar to that of the parent Ae. tauschii and significantly greater exclusion than that of the durum parent [29] at both high and moderate levels of salt. Indeed, some of the synthetic hybrids produced have significantly lower shoot $\mathrm{Na}^{+}$accumulation than bread wheat and often greater yield under salt stress conditions [80, 93]. These results indicate that the approach clearly has validity.

The use of wild relatives in breeding programs remains controversial as few salt tolerant crops are released through this approach [39, 189] Wheat was one of the earliest crops to be crossed with halophytic wild relatives but over 25 years have elapsed since that initial cross, and no new tolerant varieties has yet been released to farmers [39]. However, a report of significant yield advantage in a saline field site of durum wheat plants incorporating a $\mathrm{Na}^{+}$-excluding locus, Nax2, from $T$ monococcum appears to be particularly promising [94].

A considerable disadvantage with introducing salinity tolerance traits into crops which are already well adapted for cultivation is the introduction of undesirable traits encoded by genes, which may be physically close to the desirable gene for salinity tolerance in the plant genome [80]. This is a particular problem when breeding current crop varieties with wild relatives, as cultivated crops have been designed by breeders for thousands of years to have desirable traits such as high grain yield, appropriate height, and disease resistance. When new traits are introduced into crops by breeding, it is not possible to introduce only the gene responsible for that trait. The piece of DNA introduced from the wild relative can be quite large and will contain many genes, for most of which the functions are unknown. If these genes have an undesirable effect which impacts on the agricultural value of the crop leading, for example, to lower yield or cause incorrect flowering time, the crop will be of no value to a farmer. This phenomenon is known as linkage drag $[39,80]$. It is possible to reduce the size of the DNA insertion from the wild species by breeding the line with a cultivated crop as, over time, fragments of the wild species' DNA will be replaced by that of the cultivated crop. This process, however, can take many generations and requires the breeder to have a molecular marker specific to the $\mathrm{Na}^{+}$tolerance gene that has been inserted into the genome; otherwise this gene also would be lost [80]. Recent developments in precision breeding in combination with reducing generation time, through speed breeding [185-187], will aid the development of salt tolerant crops by considerably reducing the length of time it takes to introduce a desired trait into a crop. Speed breeding involves growing plants under stressful light and watering regimes to shorten time to flowering [185]. Combined with embryo rescue, where an embryo is removed from a 
developing grain, speed breeding can dramatically reduce the time from going from seed to seed. In recent years, it is possible to produce six generations of spring wheat (Triticum aestivum, durum wheat (T. durum), barley (Hordeum vulgare), chickpea (Cicer arietinum), and pea (Pisum sativum) per year, instead of the current two-three generations using traditional breeding [185].

\section{Molecular Breeding Technologies to Generate a Salt Tolerant Crop}

Transgenic approaches are attractive in the generation of salinity tolerant plants, as the sequences of genes known to encode proteins involved in salinity tolerance can be artificially introduced directly into the target variety, without the compounding effects of bringing in multiple, and often undesirable, genes through traditional breeding approaches. In theory, the transformation of commercially relevant crop plants directly with genes for salinity tolerance would help to reduce the time required before farmers can use these crops in the field.

There are numerous possibilities for generating transgenic crops with increased salinity tolerance, either by introducing novel genes for salinity tolerance into crops from other plant species or by altering the expression of existing genes within the crop (see Fig. 2 for example).

Plants have been generated which are better able to compartmentalize $\mathrm{Na}^{+}$in the vacuole, where $\mathrm{Na}^{+}$can accumulate to high levels without detrimental effects on the plant cells. Central to this process of vacuolar compartmentation is a gene encoding a vacuolar $\mathrm{Na}^{+}$or $\mathrm{K}^{+} / \mathrm{H}^{+}$antiporter (NHX), which transports $\mathrm{Na}^{+}$or $\mathrm{K}^{+}$into the vacuole in exchange for a proton $\left(\mathrm{H}^{+}\right)[1,95,96,166$, 179] (Fig. 2). The activity of this transporter has been shown to increase under salinity, and it is expressed in a variety of different plant species including wheat [156], barley [97], maize [98], sunflower [99], tomato [100], cotton [101], and Arabidopsis [102]. Constitutive expression in yeast of the $N H X$ gene from Arabidopsis, AtNHX1, had the effect of significantly increasing the salinity tolerance of the yeast [103, 104]. Transgenic plants, which have been created to constitutively overexpress the same Arabidopsis AtNHX gene, such as Arabidopsis [105], tomato [106], Brassica napus [107], and cotton [108], also show increased $\mathrm{Na}^{+}$accumulation in the shoot and greater salinity tolerance. These plants are, therefore, $\mathrm{Na}^{+}$tissue tolerators. Importantly from a farmer and a consumer point of view, $\mathrm{Na}^{+}$accumulation only occurred in the green tissue and not in the fruit, as in the case for tomato [106]. Of particular interest is that both increasing or decreasing the expression of the Arabidopsis AtNHX gene has been shown to significantly affect the expression patterns of other genes involved in salinity tolerance mechanisms $[96,109,110]$. This finding has significant implications for the generation of transgenic crops as it indicates that it may not be necessary to transform a plant with multiple salinity tolerant genes but rather with one gene that can regulate others.

Several homologues of the AtNHX1 gene have now been identified in a number of crops including wheat [111, 112, 156], barley [113], cotton [101], Medicago [114], Maize [98], and rice [115, 116], and the constitutive overexpression of these genes in Arabidopsis [111], rice [115-117], wheat [118], tobacco [101], and barley [113] has also been reported to improve salinity tolerance.

While there have been reports showing an increase in the salt tolerance of plants expressing NHX genes, there are also studies where no link was found between enhanced $N H X$ expression and salinity tolerance. No link could be found between $N H X 1$ and $N H X 2$ expression and salinity tolerance in three cultivars of barley [190], while transgenic barley expressing AtNHXI were found to have no significant increase in salinity tolerance under the conditions tested [191]. These observations, combined with recent reports that NHX proteins preferably transporting $\mathrm{K}^{+}$rather than $\mathrm{Na}^{+}$[166], make the role of NHXs in plant salinity tolerance ambiguous [152].

Other candidate gene families for enhancing compartmentation of ions within the vacuole through increasing the electrochemical potential difference for $\mathrm{H}^{+}$across the vacuolar membrane, and therefore salinity tolerance, are the vacuolar $\mathrm{H}^{+}$pyrophosphatase $[1,96,119]$ and vacuolar $\mathrm{H}^{+}$ATPase genes [194]. These genes do not encode 


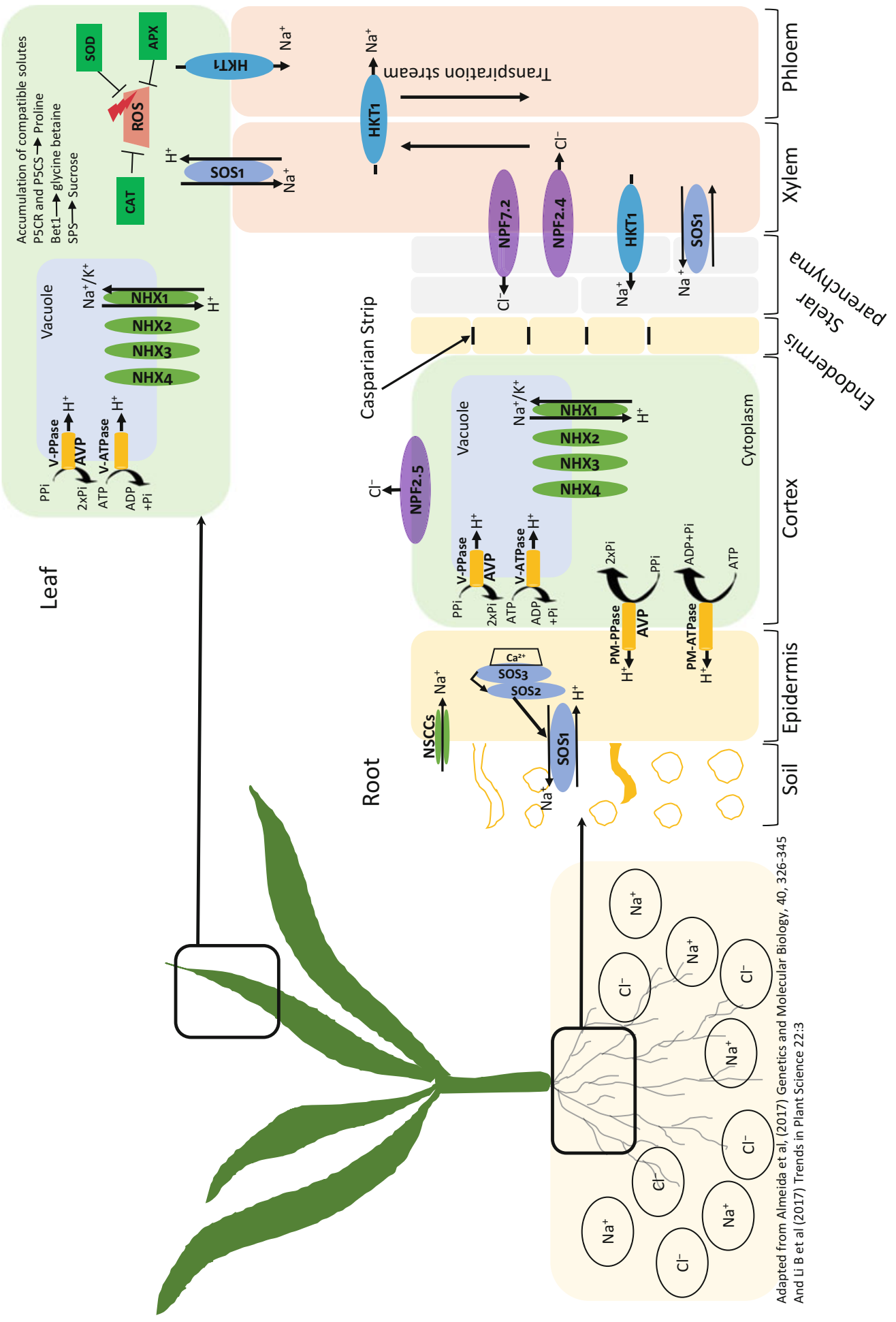

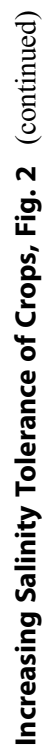


proteins that are directly responsible for the transport of $\mathrm{Na}^{+}$into the vacuole, but rather ones that use the energy released from the breakdown of the high energy molecule inorganic pyrophosphate (PPi) or (ATP) to initiate an electrochemical potential difference for $\mathrm{H}^{+}$across the tonoplast that can be used by antiporter transporters, such as NHXs, to move ions into the vacuole [194] (Fig. 2). Both ATP and PPi are widely available in a plant cell. ATP is produced by glycolysis and the citric acid cycle, while PPi is produced as a by-product of a wide range of biosynthetic pathways including DNA synthesis. Use of PPi as an energy donor for the activity of the vacuolar $\mathrm{H}^{+}$-PPase allows ATP to be conserved and improves plant cell performance under more demanding environmental conditions. In Arabidopsis, AVP1 encodes a vacuolar $\mathrm{H}^{+}$pyrophosphatase protein responsible for generating an electrochemical potential for $\mathrm{H}^{+}$across the tonoplast. Analysis of plants that are growing under salt stress, such as barley and Arabidopsis, reveals that vacuolar pyrophosphatase genes are significantly upregulated [102, 113]. Arabidopsis, alfalfa (Medicago sativa), tobacco (Nicotiana tabacum), bentgrass (Agrostis stolonifera L.), and rice plants genetically engineered to either express $A V P 1$ alone or in combination with $N H X$ have been shown to have increased salinity tolerance [111, 117, 119-122]. Transgenic alfalfa constitutively overexpressing AtAVP1 maintained a greater shoot biomass than wild type alfalfa when grown on $200 \mathrm{mM} \mathrm{NaCl}$ [122]. Similarly, transgenic bentgrass expressing the AtAVP1 gene was not greatly affected when grown on $100 \mathrm{mM}$ $\mathrm{NaCl}$ and was able to survive salt stress of 200 and $300 \mathrm{mM} \mathrm{NaCl}$, levels that are severely reduced the growth of wild type bentgrass [123]. In addition to enhanced shoot biomass and the ability to accumulate high concentrations of $\mathrm{Na}^{+}$in the shoots, other beneficial phenotypes have been observed in plants expressing pyrophosphatases, including increased root biomass and therefore increased water uptake [193], increased grain yield in barley [192], and increased fiber yield in cotton [193]. There are reports of transgenic plants performing better than wild type controls in optimal conditions [194].

In addition to the success in generating salt tolerant plants using genes involved in the mechanisms for sequestering $\mathrm{Na}^{+}$in the vacuole, transformation of plants with genes controlling other processes, such as exclusion of $\mathrm{Na}^{+}$from the plant, has also been successful. Other candidate genes for increasing the salinity tolerance of crop plants include members of the Salt Overly Sensitive (SOS) pathway.

Many aspects of plant growth, development, and responses to environmental stresses are mediated by the calcium ion $\left(\mathrm{Ca}^{2+}\right)$ as a secondary messenger signaling molecule. The external cue is first perceived by receptors on the plant cell membrane and this then activates a signaling cascade, using calcium, which regulates the activities of proteins and gene expression [124-127]. The SOS pathway mediates the response of a plant cell

\section{Increasing Salinity Tolerance of Crops,}

Fig. 2 Intracellular location of proteins in a plant which are encoded by candidate genes for transformation into transgenic crop plants. NHX1 is a transporter, which is involved in the compartmentation of $\mathrm{Na}^{+} / \mathrm{K}^{+}$into the vacuole by swapping a cytoplasmic $\mathrm{Na}^{+} / \mathrm{K}^{+}$ion with a vacuolar proton $\left(\mathrm{H}^{+}\right)$. AVP is a proton pump that uses the energy released from the hydrolysis of PPi to move protons into the endodermis or the vacuole. These protons can then be used by transporters such as NHX to transport $\mathrm{Na}^{+} / \mathrm{K}^{+}$into the vacuole. HKT proteins are involved in the transport of $\mathrm{Na}^{+}$from the extracellular space (apoplast) into the cytoplasm. In the salt overly sensitive (SOS) pathway, high concentrations of $\mathrm{Na}^{+}$are detected by a membrane bound salt sensor, which results in the release of $\mathrm{Ca}^{2+}$ to the cytoplasm. This cytoplasmic $\mathrm{Ca}^{2+}$ binds to the calcium binding protein SOS3, which activates the protein kinase SOS2. Together SOS3 and SOS2 activate the $\mathrm{Na}^{+}$transporting ability of the SOS1, which moves $\mathrm{Na}^{+}$out of the cell. Anion transporters, such as $\mathrm{Cl}^{-}$transporter AtNPF2.5, are localized to plasma membrane and play a role in $\mathrm{Cl}^{-}$efflux from root to soil, while others, such as AtNPF2.4 and AtNPF7.2, are involved in $\mathrm{Cl}^{-}$xylem loading and retrieval, respectively. To balance osmotic pressure, plants accumulate compatible solutes such as proline, glycine betaine and sucrose, in the cytosol of cells. To detoxify dangerous reactive oxygen species (ROS) they use a variety of enzymes includingsuperoxide dismutase (SOD), ascorbate peroxidase (APX) and catalase (CAT). (Adapted from [174, 200]) 
to salinity stress. The SOS pathway was so named due to the extreme salt sensitivity of plants, which had mutations in key genes of this pathway [128]. Initially, three genes from these mutants, AtSOS1, AtSOS2, and AtSOS3, were identified in Arabidopsis as being important in salinity tolerance [129]. It should be noted, however, that the SOS name refers to a specific salt sensitive phenotype and that the genes sharing the same SOS identifier are unrelated to each other. Indeed, the proteins encoded by these genes are quite different: AtSOS1 is a plasma membrane $\mathrm{Na}^{+}$transporter [130]; AtSOS2 is a protein kinase belonging to a large family of Calcineurin B-like Interacting Protein Kinases (CIPKs) [125, 127]; and AtSOS3 is a plasma membrane bound $\mathrm{Ca}^{2+}$ binding protein which belongs to the Calcineurin B-Like proteins (CBL) [125, 127]. However, although they have completely different functions, it is the interactions of these proteins that help a plant cell survive salt stress.

It has been shown in Arabidopsis that, under salt stress, $\mathrm{Ca}^{2+}$ is released into the plant cell cytoplasm from either internal or external cellular stores and it binds to the plasma membrane bound AtSOS3 (AtCBL4). CBL proteins have specific regions that allow them to bind to specific CIPKs, such as SOS2. When $\mathrm{Ca}^{2+}$ becomes bound to AtSOS3, it recruits AtSOS2 to the plasma membrane where the kinase phosphorylates the $\mathrm{Na}^{+}$/ $\mathrm{H}^{+}$antiporter AtSOS1, thereby activating the transporter and allowing the movement of $\mathrm{Na}^{+}$ out of the cell [1, 124, 125, 127, 157] (Fig. 2). Although these genes were identified initially in Arabidopsis, homologues for all three genes have now been discovered in a variety of plant species, including crops, such as Thellungiella halophila [131], poplar [132], tomato [158], wheat [195], and rice [133]. In all of these species, the genes involved in the SOS pathway have been shown to be significantly upregulated under salt stress, particularly in the plant roots. This would make them ideal as candidate genes for transformation into transgenic crops to increase salinity tolerance.

Arabidopsis plants that were engineered to constitutively express the AtSOS1 gene had significantly increased salinity tolerance, showing greater biomass, increased chlorophyll retention, and reduced concentrations of $\mathrm{Na}^{+}$in the shoot when compared to wild type plants when grown under high saline conditions [134]. Importantly, these plants were reported not to suffer any growth penalty when grown under nonstressed conditions. The increase in the salinity tolerance of the transgenic plants was attributed to them having a greater efflux of $\mathrm{Na}^{+}$at the cellular level when compared to control plants.

While the above examples have focused primarily on the ability to manipulate the transport of $\mathrm{Na}^{+}$through a plant or cell, it is also possible to manipulate the movement of $\mathrm{Cl}^{-}$through a plant to enhance salt tolerance. The Nitrate transporter 1/Peptide Transporter family 2.4 gene (NPF2.4) was found to be expressed in root stellar tissue and involved in the loading of $\mathrm{Cl}^{-}$into the xylem [196]. Knocking down the expression of this gene using an artificial micro-RNA (amiRNA) results in plants with reduced $\mathrm{Cl}^{-}$accumulation in the shoot of Arabidopsis plants [196]. Taking a similar approach in those crops where $\mathrm{Cl}^{-}$is more toxic than $\mathrm{Na}^{+}$may enhance their salinity tolerance.

It is not always necessary to generate a salt tolerant plant by altering the expression level of a gene that encodes a transporter of ions. The salinity tolerance of a plant can also be increased by overexpressing genes encoding molecules that are involved in signaling or in activating genes. Overexpression of the transcription factor Alfin1 in alfalfa resulted in plants with increased root and shoot growth under both control and salt stressed conditions [135]. Enhanced expression of genes involved in signaling pathways, such as those encoding calcium binding CBL proteins and the protein kinase CIPKs, increases the salt tolerance of Arabidopsis, rice, poplar, and tobacco [136-139, 215-217], presumably through enhancing the signaling response of the cell when it is under salt stress. However, the way in which some genes contribute to overall salt tolerance remains unclear. Transgenic tomato that had been transformed with the yeast gene HAL1 showed increased salt tolerance under stressed conditions but had reduced shoot weight when grown in control conditions, significantly lower than nontransformed plants [140]. This 
demonstrates that there remains significantly more to understand about the timing and regulation of genes in planta before a transgenic salt tolerant plant can successfully be produced.

When generating transgenic plants, it is important to consider the type of promoter used to control the gene of interest. Certain genes that have been identified as important for plant salinity tolerance have nevertheless not been shown to increase the salinity tolerance of genetically modified plants when constitutively overexpressed. For example, although the HKT gene family has been shown to be important in salinity tolerance, the constitutive overexpression of an $H K T$ gene was found to have a detrimental effect. The $H K T$ gene family can be divided into those genes encoding a $\mathrm{Na}^{+}$transporting protein (subfamily 1) or a $\mathrm{K}^{+} / \mathrm{Na}^{+}$transporting protein (subfamily 2) $[23,74]$. Members of subfamily 2 are considered to be involved in nutrition and the uptake from the soil of ions essential to plant growth (small quantities of $\mathrm{Na}^{+}$can be beneficial to plant growth) [141-144], whereas members of subfamily 1 are believed to be important for plant salt tolerance [1, 23, 96, 160]. Members of the subfamily $1 H K T$ gene family have been shown to encode proteins important for the retrieval of $\mathrm{Na}^{+}$from the xylem in both the root and the shoot, thereby reducing the accumulation of $\mathrm{Na}^{+}$in the shoot $[23,74,75$, $79,96,145,160]$. The protein moves $\mathrm{Na}^{+}$from the transpiration stream into the cells surrounding the xylem (Fig. 2). Evidence for this function has now been found in a number of plant species in addition to Arabidopsis, such as rice [70], barley [200] and wheat $[72,73,160]$. Both naturally occurring ecotypes and mutant lines of Arabidopsis, which have reduced expression of this gene, show increased shoot $\mathrm{Na}^{+}$accumulation $[75,102,146$, 147]. However, constitutive overexpression of this subfamily $1 H K T$ gene also results in higher concentrations of $\mathrm{Na}^{+}$and salt sensitive plants [77]. As HKT proteins move $\mathrm{Na}^{+}$into cells, the increased salt sensitivity of constitutive overexpressing plants may be due to the fact that when the gene is expressed throughout the plant, the protein encoded by the gene transports more $\mathrm{Na}^{+}$from the soil into the root, resulting in more $\mathrm{Na}^{+}$being transported to the shoot in the transpiration stream. Expression of this gene only in the cells surrounding the xylem would result in a plant being more efficient in retrieving $\mathrm{Na}^{+}$from the transpiration stream.

Plants consist of multiple tissues and multiple cells. Each tissue is adapted for a specific purpose - roots for nutrient uptake, leaves for photosynthesis, stems for support - and, therefore, will not necessarily express the same genes. Genes responsible for the maintenance of photosynthesis in the leaves will not be expressed in the roots, and genes for nutrient uptake from the soil will not be expressed in floral tissue. Similarly, not all genes in a plant are expressed all the time; many genes are activated only when required. When growing in nonstressed environments, there is little point in a plant using critical energy supplies to generate and maintain proteins important for salinity tolerance. It is unsurprising, therefore, that the continuous expression throughout a plant of a gene important for salinity tolerance, such as AtHKT1;1, often results in detrimental effects [77]. A critical feature in the generation of crops engineered to have increased salinity tolerance is the spatial and temporal control of the transgene that has been introduced.

Transgenic Arabidopsis plants have been produced with cell-specific expression of the AtHKT1; 1 gene in the root cells surrounding the xylem [148]. Unlike plants with constitutive overexpression of AtHKT1; 1 , these cell-specific plant lines showed a significant reduction in shoot $\mathrm{Na}^{+}$ and increased salt tolerance [148]. However, in the recent studies, HKT1 was also described to have a negative impact on the development of lateral roots under saline conditions [167].

In a different approach, rice plants designed to overexpress a gene involved in the synthesis of trehalose only when the plants experienced stress exhibited reduced shoot $\mathrm{Na}^{+}$concentrations and better growth in saline conditions than nontransformed plants [149]. Trehalose is a sugar involved in protecting cells from long periods of desiccation and possibly aids salinity tolerance through an ability to scavenge reactive oxygen species, thereby protecting cellular proteins [39]; however, plants with constitutive overexpression of genes for trehalose synthesis display severe 
stunting [150]. The use of a stress-inducible promoter is, therefore, an important control to minimize growth inhibition of transgenic plants when grown in nonstressed environments. The focus now is the identification of gene promoters (sequences of DNA which are used to activate genes) that allow the cell- and temporal-specific expressions of genes in crops.

In addition to the fine control of genes transformed into transgenic crops, there is also the need to identify gene combinations, which may have the potential to increase crop salt tolerance. As has been observed, plants employ multiple salinity tolerance mechanisms to survive saline soils, all of which rely on a variety of different genes and proteins. It seems unlikely, therefore, that the generation of a successful commercial salt tolerant crop will be achieved by the constitutive overexpression of one single gene. Some research promoting salt tolerance in plants focuses either on boosting the intracellular salt-sequestering processes or on the $\mathrm{Na}^{+}$exclusion mechanisms by transferring into selected crop species genes for salinity tolerance from model organisms (such as Arabidopsis) or from salt tolerant plants. A complementary approach focuses on the challenging task of reducing net input of salt into plants by perturbing the function of channels and transporters involved in sodium uptake but without disturbing potassium uptake. An ideal scenario contemplates the generation of transgenic plants with an enhanced capability for vacuolar salt sequestration combined with a reduced uptake of salt. While a number of genes involved in these processes have now been identified, the challenge is to switch these genes on at the appropriate time and in the appropriate tissues where they can be most effective. In order to achieve this aim, improved knowledge is required of gene promoters that are stress inducible and cell specific.

While it is clear that there are potentially many avenues for the generation of a genetically modified salt tolerant plant, there remain significant challenges. Although it is now possible to generate salt tolerant plants in a laboratory, it has yet to be shown whether this relates to actual yield improvements in the field. There are cases where using genetic modification to generate a salt tolerant plant has a negative effect on yield when no stress is present. It is clear, therefore, that more information on gene promoters is required to enable the activation of salt tolerant genes in specific tissues/cell types only when plants are grown in salt. Furthermore, there are areas of the world, such as Europe, where there remains considerable resistance to the acceptance of genetically modified plants. This may well be due to the lack of availability to consumers of clear, accurate information, as well as the prevalence of extremist views. A more open, transparent approach by scientists is required explaining the potential advantages and disadvantages of this technology. Only then will consumers be able to make their own informed choices about genetically modified organisms.

Recently, new breeding technologies have emerged which may overcome the limitations experienced with transgenic approaches. Clustered Regularly Interspaced Short Palindromic Repeats (CRISPR/Cas9), transcription activatorlike effector-based nucleases (TALENs), and zinc finger nucleases (ZNFs) are ways to make targeted alterations to a plant's DNA [197]. Collectively known as genome editing, these approaches can introduce SNPs, delete target regions of DNA, or insert DNA (such as genes). CRISPR/Cas9 was recently used to replicate the domestication of tomato by targeting known domestication genes in the wild salt tolerant tomato relative Solanum pimpinellifolium [198]. By simply targeting genes involved in self-pruning, the edited S. pimpinellifolium plants exhibited a phenotype more similar to its domesticated relative, while retaining its salinity tolerance [198]. Currently, there is no universal view as to whether genome editing technologies will be regulated in a similar way to more traditional GM approaches. The United States Department of Agriculture has announced it has no plans to regulate edited plants which contain modifications to DNA which could have been introduced through traditional breeding approaches. The European Union, however, has ruled that genome edited plants will still be subject to the same regulation as conventional genetically modified plants. 


\section{Future Directions}

Crops growing on saline soils suffer severe reductions in yield due to both ionic and osmotic stresses. As considerable areas of farmland are currently affected by saline soils, much research has been undertaken to enhance crop salinity tolerance by exploitation of natural variation in salinity tolerance or through the generation of transgenic plants expressing genes shown to be important for salt tolerance. While salinity tolerant plants have been generated by both approaches, the focus should now be on the production of viable crop plants for farmers to grow in affected areas. For this to occur, the new cultivars of tolerant plants need to be tested under rigorous field conditions and those with enhanced salt tolerance and, as equally important, no yield penalties when grown in nonsaline conditions, now be passed on to breeders for incorporation into future crops.

Approaches are still required to help speed up the generation of salinity tolerant crops through the exploitation of natural variation. Deep and shallow coverage sequencing of already sequenced crops is helping to improve our understanding of salinity tolerance in species such as quinoa [169], barley [170], bread wheat [171], and tomato [172]. Approaches using modern imaging technologies, as well as unmanned aerial vehicles for field phenotyping, are speeding up the identification of candidate genes underlying salt tolerance QTL. For example, a new locus related to transpiration use efficiency (TUE) was identified in rice [168], providing a basis for testing the importance of early responses to salinity on yield in the field. Studying allelic variation of the characterized molecular components, such as HKT1, is another example of hypothesis driven approach that is valuable in identifying important allelic variants that will shed more light on functionality of individual genes [174].

For transgenic plants, it is clear that there is still debate over their regulation and acceptance in today's society. This makes the pathway to target for many transgenic crops difficult. However, while it may take a long time for salinity tolerant transgenic crops to appear in the market place, there is still a need for using transgenic plants in proof of concept studies, which will enable a greater understanding of the mechanisms behind salinity tolerance and how to manipulate them. Already the use of transgenic plants shown us many genes that can be used to enhance salt tolerance and that control over when and where a gene is expressed is essential. As there are now multiple candidate genes, with potential for enhancing salinity tolerance, research should now focus more on identifying the controlling elements in a plant's genome, which dictate when and where a gene is expressed, and less on the identification of candidate genes. In addition, combinations of genes that have additive effects on salinity tolerance need to be identified, thereby allowing the production of the most optimal salt tolerant plants. When these factors are known, plants can be produced which have the ability to activate multiple genes for salinity tolerance in different areas of the plant but only when saline soils are experienced. These plants may be produced via traditional genetic modification techniques or by genome editing

Although further research is clearly still required, considerable progress has been made in generating salt tolerant plants through the exploitation of natural variations and the generation of genetically modified organisms. The next step is to deliver salt tolerant crops to farmers.

\section{Bibliography}

\section{Primary Literature}

1. Munns R, Tester M (2008) Mechanisms of salinity tolerance. Annu Rev Plant Biol 59:651-681

2. FAO (2008) FAO Land and Plant Nutrition Management Service. Available from http://www.fao.org/ag/ agl/agll/spush

3. Szabolcs I (1989) Salt-affected soils. CRC Press, Boca Raton

4. Munns R (2002) Comparative physiology of salt and water stress. Plant Cell Environ 25:239-250

5. Flowers TJ, Hajibagherp MA, Yeo AR (1991) Ion accumulation in the cell walls of rice plants growing under saline conditions: evidence for the Oertli hypothesis. Plant Cell Environ 14:319-325

6. Munns R, James RA, Lauchli A (2006) Approaches to increasing the salt tolerance of wheat and other cereals. J Exp Bot 57:1025-1043 
7. Yeo AR et al (1991) Short- and long-term effects of salinity on leaf growth in rice (Oryza sativa L.). J Exp Bot 42:881-889

8. Frensch J, Hsiao TC (1994) Transient responses of cell turgor and growth of maize roots as affected by changes in water potential. Plant Physiol 104:247-254

9. Hu Y et al (2007) Short-term effects of drought and salinity on mineral nutrient distribution along growing leaves of maize seedlings. Environ Exp Bot 60:268-275

10. Hu Y, Fricke W, Schmidhalter U (2005) Salinity and the growth of non-halophytic grass leaves: the role of mineral nutrient distribution. Funct Plant Biol 32:973-985

11. Fricke W (2004) Rapid and tissue-specific accumulation of solutes in the growth zone of barley leaves in response to salinity. Planta 219:515-525

12. Termaat A, Munns R (1986) Use of concentrated macronutrient solutions to separate osmotic from $\mathrm{NaCl}$ specific effects on plant growth. Aust J Plant Physiol 13:509-522

13. Munns R et al (2000) Leaf water status controls daytime but not daily rates of leaf expansion in salttreated barley. Aust J Plant Physiol 27:949-957

14. Fricke W, Peters WS (2002) The biophysics of leaf growth in salt-stressed barley. A study at the cell level. Plant Physiol 129:374-388

15. Fricke W et al (2004) Rapid and tissue-specific changes in ABA and in growth rate in response to salinity in barley leaves. J Exp Bot 55:1115-1123

16. Apel K, Hirt H (2004) Reactive oxygen species: metabolism, oxidative stress and signal transduction. Annu Rev Plant Biol 55:373-399

17. Logan BA (2005) Reactive oxygen species and photosynthesis. In: Smirnoff N (ed) Antioxidants and reactive oxygen species in plants. Blackwell, Oxford, pp 250-267

18. Tester M, Davenport R (2003) $\mathrm{Na}^{+}$tolerance and $\mathrm{Na}^{+}$ transport in higher plants. Ann Bot 91:503-527

19. Storey R, Walker RR (1999) Citrus and salinity. Sci Hortic 78:39-81

20. Flowers TJ, Yeo AR (1988) Ion relations of salt tolerance. In: Baker D, Halls J (eds) Solute transport in plant cells and tissues. Longman, Harlow, pp 392-416

21. Läuchli A (1984) Salt exclusion: an adaptation of legumes for crops and pastures under saline conditions. In: Staples RC (ed) Salinity tolerance in plants: strategies for crop improvement. Wiley, New York, pp 171-187

22. Teakle NL, Tyerman SD (2010) Mechanisms of $\mathrm{Cl}^{-}$ transport contributing to salt tolerance. Plant Cell Environ 33:566-589

23. Horie T, Hauser F, Schroeder JI (2009) HKT transporter-mediated salinity resistance mechanisms in Arabidopsis and monocot crop plants. Trends Plant Sci 14:660-668
24. Bhandal IS et al (1988) Potassium estimation, uptake, and its role in the physiology and metabolism of flowering plants. Int Rev Cytol 110:205-254

25. Wyn Jones RG, Brady CJ, Spears J (1979) Ionic and osmotic relations in plant cells. In: Laidman DL, Wyn Jones RG (eds) Recent advances in the biochemistry of cereals. Academic, London, pp 63-103

26. Blaha $\mathrm{G}$ et al (2000) Preparation of functional ribosomal complexes and effect of buffer conditions on tRNA positions observed by cryoelectron microscopy. Methods Enzymol 317:292-306

27. Munns R (1993) Physiological processes limiting plant growth in saline soils: some dogmas and hypotheses. Plant Cell Environ 16:15-24

28. Öertli JJ (1968) Extracellular salt accumulation, a possible mechanism of salt injury in plants. Agrochimica 12:461-469

29. Gorham J (1990) Salt tolerance in the Triticeae: K/Na discrimination in synthetic hexaploid wheats. J Exp Bot 41:623-627

30. Dubcovsky J et al (1996) Mapping of the $\mathrm{K}^{+} / \mathrm{Na}^{+}$ discrimination locus Knal in wheat. Theor Appl Genet 92:448-454

31. Maathuis FJM, Amtmann A (1999) $\mathrm{K}^{+}$nutrition and $\mathrm{Na}^{+}$toxicity: the basis of cellular $\mathrm{K}^{+} / \mathrm{Na}^{+}$ratios. Ann Bot 84:123-133

32. Hu YC, Schnyder H, Schmidhalter U (2000) Carbohydrate deposition and partitioning in elongating leaves of wheat under saline soil conditions. Aust J Plant Physiol 27:363-370

33. Chen THH, Murata N (2002) Enhancement of tolerance of abiotic stress by metabolic engineering of betaines and other compatible solutes. Curr Opin Plant Biol 5:250-257

34. Aslam $\mathrm{Z}$ et al (1986) Effects of external $\mathrm{NaCl}$ on the growth of Atriplex amnicola and the ion relations and carbohydrate status of the leaves. Plant Cell Environ 9:571-580

35. Glenn EP, Brown JJ, Blumwald E (1999) Salt tolerance and crop potential of halophytes. Crit Rev Plant Sci 18:227-255

36. Aslam M, Qureshi RH, Ahmed N (1993) A rapid screening technique for salt tolerance in rice (Oryza sativa L.). Plant Soil 150:99-107

37. Walia $\mathrm{H}$ et al (2005) Comparative transcriptional profiling of two contrasting rice genotypes under salinity stress during the vegetative growth stage. Plant Physiol 139:822-835

38. Flowers TJ, Yeo AR (1981) Variability in the resistance of sodium chloride salinity within rice (Oryza sativa L.) varieties. New Phytol 88:363-373

39. Flowers TJ (2004) Improving crop salt tolerance. J Exp Bot 55:307-319

40. Garthwaite AJ, von Bothmer R, Colmer TD (2005) Salt tolerance in wild Hordeum species is associated with restricted entry of $\mathrm{Na}^{+}$and $\mathrm{Cl}^{-}$into the shoots. J Exp Bot 56:2365-2378 
41. Munns R, James RA (2003) Screening methods for salinity tolerance: a case study with tetraploid wheat. Plant Soil 253:201-218

42. Flowers TJ et al (2010) Salt sensitivity in chickpea. Plant Cell Environ 33:490-509

43. Greenway H, Munns R (1980) Mechanisms of salt tolerance in nonhalophytes. Annu Rev Plant Physiol 31:149-190

44. Sengupta S, Majumder AL (2010) Porteresia coarctata (Roxb.) Tateoka, a wild rice: a potential model for studying salt-stress biology in rice. Plant Cell Environ 33:526-542

45. James RA et al (2008) Genetic variation in tolerance to the osmotic stress component of salinity stress in durum wheat. Funct Plant Biol 35:111-123

46. James RA et al (2002) Factors affecting $\mathrm{CO}_{2}$ assimilation, leaf injury and growth in salt-stressed durum wheat. Funct Plant Biol 29:1393-1403

47. Silva C, Martínez V, Carvajal M (2008) Osmotic versus toxic effects of $\mathrm{NaCl}$ on pepper plants. Biol Plant 52:72-79

48. Rajendran K, Tester M, Roy SJ (2009) Quantifying the three main components of salinity tolerance in cereals. Plant Cell Environ 32:237-249

49. Sirault XRR, James RA, Furbank RT (2009) A new screening method for osmotic component of salinity tolerance in cereals using infrared thermography. Funct Plant Biol 36:970-977

50. Poustini K, Siosemardeh A (2004) Ion distribution in wheat cultivars in response to salinity stress. Field Crop Res 85:125-133

51. Lee K-S et al (2003) Salinity tolerance of japonica and indica rice (Oryza sativa L.) at the seedling stage. Planta 216:1043-1046

52. Zhu GY, Kinet JM, Lutts S (2001) Characterization of rice (Oryza sativa L.) F3 populations selected for salt resistance. I. Physiological behaviour during vegetative growth. Euphytica 121:251-263

53. Forster B (2001) Mutation genetics of salt tolerance in barley: an assessment of Golden Promise and other semi-dwarf mutants. Euphytica 120:317-328

54. Wei W et al (2003) Salinity induced differences in growth, ion distribution and partitioning in barley between the cultivar Maythorpe and its derived mutant Golden Promise. Plant Soil 250:183-191

55. Teakle $\mathrm{N}$ et al (2007) Lotus tenuis tolerates the interactive effects of salinity and waterlogging by 'excluding' $\mathrm{Na}^{+}$and $\mathrm{Cl}^{-}$from the xylem. J Exp Bot 58:2169-2180

56. Sibole JV et al (2003) Ion allocation in two different salt-tolerant Mediterranean Medicago species. J Plant Physiol 160:1361-1365

57. Kingsbury RW, Epstein E (1984) Selection for saltresistant spring wheat. Crop Sci 24:310-315

58. Jafari-Shabestari J, Corke H, Qualset C (1995) Field evaluation of tolerance to salinity stress in Iranian hexaploid wheat landrace accessions. Genet Resour Crop Evol 42:147-156
59. Munns R et al (2000) Genetic variation for improving the salt tolerance of durum wheat. Aust J Agric Res 51:69-74

60. Richards RA et al (1987) Variation in yield of grain and biomass in wheat, barley, and triticale in a saltaffected field. Field Crop Res 15:277-287

61. Slavich P, Read B, Cullis B (1990) Yield response of barley germplasm to field variation in salinity quantified using the EM-38. Aust J Exp Agric 30:551-556

62. Lee J-D et al (2009) Inheritance of Salt Tolerance in Wild Soybean (Glycine soja Sieb. and Zucc.) Accession PI483463. J Hered 100:798-801

63. Tozlu I, Guy CL, Moore G (1999) QTL analysis of $\mathrm{Na}^{+}$and $\mathrm{Cl}^{-}$accumulation related traits in an intergeneric $\mathrm{BC}_{1}$ progeny of Citrus and Poncirus under saline and nonsaline environments. Genome Biol 42:692-705

64. Vadez V et al (2007) Large variation in salinity tolerance in chickpea is explained by differences in sensitivity at the reproductive stage. Field Crop Res 104:123-129

65. Gregorio GB et al (2002) Progress in breeding for salinity tolerance and associated abiotic stresses in rice. Field Crop Res 76:91-101

66. Sahi $\mathrm{C}$ et al (2006) Salt stress response in rice: genetics, molecular biology, and comparative genomics. Funct Integr Genomics 6:263-284

67. Mano Y, Takeda K (1997) Mapping quantitative trait loci for salt tolerance at germination and the seedling stage in barley (Hordeum vulgare L.). Euphytica 94:263-272

68. Shavrukov Y et al (2010) HvNax3 - a locus controlling shoot sodium exclusion derived from wild barley (Hordeum vulgare ssp. spontaneum). Funct Integr Genomics 10:277-291

69. Bretó MP, Aśins MJ, Carbonell EA (1994) Salt tolerance in Lycopersicon species. III. Detection of quantitative trait loci by means of molecular markers. Theor Appl Genet 88:395-401

70. Ren Z-H et al (2005) A rice quantitative trait locus for salt tolerance encodes a sodium transporter. Nat Genet 37:1141-1146

71. Gorham J et al (1987) Chromosomal location of a $\mathrm{K} / \mathrm{Na}$ discrimination character in the $\mathrm{D}$ genome of wheat. Theor Appl Genet 74:584-588

72. Huang S et al (2006) A sodium transporter (HKT7) is a candidate for Nax1, a gene for salt tolerance in durum wheat. Plant Physiol 142:1718-1727

73. Byrt CS et al (2007) HKT1;5-like cation transporters linked to $\mathrm{Na}^{+}$exclusion loci in wheat, Nax2 and Knal. Plant Physiol 143:1918-1928

74. Platten JD et al (2006) Nomenclature for HKT transporters, key determinants of plant salinity tolerance. Trends Plant Sci 11:372-374

75. Davenport RJ et al (2007) $\mathrm{The} \mathrm{Na}^{+}$transporter AtHKT1; 1 controls retrieval of $\mathrm{Na}^{+}$from the xylem in Arabidopsis. Plant Cell Environ 30:497-507 
76. Huang $\mathrm{S}$ et al (2008) Comparative mapping of HKT genes in wheat, barley, and rice, key determinants of $\mathrm{Na}^{+}$transport, and salt tolerance. J Exp Bot 59:927-937

77. Rus A et al (2004) AtHKT1 facilitates $\mathrm{Na}^{+}$homeostasis and $\mathrm{K}^{+}$nutrition in Planta. Plant Physiol 136:2500-2511

78. Rus A et al (2001) AtHKT1 is a salt tolerance determinant that controls $\mathrm{Na}^{+}$entry into plant roots. Proc Natl Acad Sci U S A 98:14150-14155

79. Sunarpi $\mathrm{H}$ et al (2005) Enhanced salt tolerance mediated by AtHKT1 transporter-induced $\mathrm{Na}^{+}$unloading from xylem vessels to xylem parenchyma cells. Plant J 44:928-938

80. Colmer TD, Flowers TJ, Munns R (2006) Use of wild relatives to improve salt tolerance in wheat. J Exp Bot 57:1059-1078

81. Dvořák J, Gorham J (1992) Methodology of gene transfer by homoeologous recombination into Triticum turgidum: transfer of $\mathrm{K}^{+} / \mathrm{Na}^{+}$discrimination from Triticum aestivum. Genome Biol 35:639-646

82. Dvořak J et al (1994) Enhancement of the salt tolerance of Triticum turgidum L. by the Knal locus transferred from the Triticum aestivum L. chromosome 4D by homoeologous recombination. Theor Appl Genet 87:872-877

83. Gorham J et al (1997) Genetic analysis and physiology of a trait for enhanced $\mathrm{K}^{+} / \mathrm{Na}^{+}$discrimination in wheat. New Phytol 137:109-116

84. Perez-Alfocea F et al (1994) Comparative salt responses at cell and whole-plant levels of cultivated and wild tomato species and their hybrid. J Hortic Sci Biotechnol 69:639-644

85. Sherraf I et al (1994) Production and characterization of intergeneric somatic hybrids through protoplast electrofusion between potato (Solanum tuberosum) and Lycopersicon pennellii. Plant Cell Tissue Organ Cult 37:137-144

86. Nevo E, Chen G (2010) Drought and salt tolerances in wild relatives for wheat and barley improvement. Plant Cell Environ 33:670-685

87. Gorham J et al (1986) Salt tolerance in the triticeae: solute accumulation and distribution in an amphidiploid derived from Triticum aestivum cv. Chinese Spring and Thinopyrum bessarabicum. J Exp Bot 37:1435-1449

88. King IP et al (1997) Introgression of salt-tolerance genes from Thinopyrum bessarabicum into wheat. New Phytol 137:75-81

89. Yan J et al (2008) Phenotypic variation in caryopsis dormancy and seedling salt tolerance in wild barley, Hordeum spontaneum, from different habitats in Israel. Genet Resour Crop Evol 55:995-1005

90. Gorham J et al (1991) The presence of the enhanced $\mathrm{K} / \mathrm{Na}$ discrimination trait in diploid Triticum species. Theor Appl Genet 82:729-736

91. James RA, Davenport RJ, Munns R (2006) Physiological characterization of two genes for $\mathrm{Na}^{+}$ exclusion in durum wheat, Nax1 and Nax2. Plant Physiol 142:1537-1547

92. Shah SH et al (1987) Salt tolerance in the Triticeae: the contribution of the $\mathrm{D}$ genome to cation selectivity in hexaploid wheat. J Exp Bot 38:254-269

93. Schachtman DP, Lagudah ES, Munns R (1992) The expression of salt tolerance from Triticum tauschii in hexaploid wheat. Theor Appl Genet 84:714-719

94. CSIRO. CSIRO develops highest yielding salt tolerant wheat (2010) Available from http://www.csiro. $\mathrm{au} /$ news/CSIRO-develops-highest-yielding-salt-toler ant-wheat.html

95. Blumwald E, Aharon GS, Apse MP (2000) Sodium transport in plant cells. Biochim Biophys Acta 1465:140-151

96. Plett DC, Skrumsager Møller I (2010) $\mathrm{Na}^{+}$transport in glycophytic plants: what we know and would like to know. Plant Cell Environ 33:612-626

97. Garbarino J, DuPont FM (1989) Rapid induction of $\mathrm{Na}^{+} / \mathrm{H}^{+}$exchange activity in barley root tonoplast. Plant Physiol Biochem 89:1-4

98. Zörb C et al (2005) Molecular characterization of $\mathrm{Na}^{+} / \mathrm{H}^{+}$antiporters $(\mathrm{ZmNHX})$ of maize (Zea mays L.) and their expression under salt stress. J Plant Physiol 162:55-66

99. Ballesteros E et al (1997) $\mathrm{Na}^{+} / / \mathrm{H}^{+}$antiport activity in tonoplast vesicles isolated from sunflower roots induced by $\mathrm{NaCl}$ stress. Physiol Plant 99:328-334

100. Wilson C, Shannon MC (1995) Salt-induced $\mathrm{Na}^{+} / \mathrm{H}^{+}$ antiport in root plasma membrane of a glycophytic and halophytic species of tomato. Plant Sci 107:147-157

101. Wu C-A et al (2004) The cotton GhNHXI gene encoding a novel putative tonoplast $\mathrm{Na}^{+} / \mathrm{H}^{+}$antiporter plays an important role in salt stress. Plant Cell Physiol 45:600-607

102. Jha D et al (2010) Variation in salinity tolerance and shoot sodium accumulation in Arabidopsis ecotypes linked to differences in the natural expression levels of transporters involved in sodium transport. Plant Cell Environ 33:793-804

103. Aharon GS et al (2003) Characterization of a family of vacuolar $\mathrm{Na}^{+} / \mathrm{H}^{+}$antiporters in Arabidopsis thaliana. Plant Soil 253:245-256

104. Gaxiola RA et al (1999) The Arabidopsis thaliana proton transporters, AtNHX1 and AVP1, can function in cation detoxification in yeast. Proc Natl Acad Sci U S A 96:1480-1485

105. Apse MP et al (1999) Salt tolerance conferred by overexpression of a vacuolar $\mathrm{Na}^{+} / \mathrm{H}^{+}$antiport in Arabidopsis. Science 285:1256-1258

106. Zhang H-X, Blumwald E (2001) Transgenic salttolerant tomato plants accumulate salt in foliage but not in fruit. Nat Biotechnol 19:765-768

107. Zhang H-X et al (2001) Engineering salt-tolerant Brassica plants: characterization of yield and seed oil quality in transgenic plants with increased vacuolar sodium accumulation. Proc Natl Acad Sci U S A 98:12832-12836 
108. He C et al (2005) Expression of an Arabidopsis vacuolar sodium/proton antiporter gene in cotton improves photosynthetic performance under salt conditions and increases fiber yield in the field. Plant Cell Physiol 46:1848-1854

109. Sottosanto J, Gelli A, Blumwald E (2004) DNA array analyses of Arabidopsis thaliana lacking a vacuolar $\mathrm{Na}+\mathrm{H}+$ antiporter: impact of AtNHX1 on gene expression. Plant J 40:752-771

110. Sottosanto J, Saranga Y, Blumwald E (2007) Impact of $A t N H X 1$, a vacuolar $\mathrm{Na}^{+} / \mathrm{H}^{+}$antiporter, upon gene expression during short- and long-term salt stress in Arabidopsis thaliana. BMC Plant Biol 7:18

111. Brini $\mathrm{F}$ et al (2007) Overexpression of wheat $\mathrm{Na}^{+} / \mathrm{H}^{+}$ antiporter TNHXI and $\mathrm{H}^{+}$-pyrophosphatase TVP1 improve salt- and drought-stress tolerance in Arabidopsis thaliana plants. J Exp Bot 58:301-308

112. Yu J et al (2007) An $\mathrm{Na}+/ \mathrm{H}+$ antiporter gene from wheat plays an important role in stress tolerance. J Biosci 32:1153-1161

113. Fukuda A et al (2004) Effect of salt and osmotic stresses on the expression of genes for the vacuolar $\mathrm{H}^{+}$-pyrophosphatase, $\mathrm{H}^{+}$-ATPase subunit $\mathrm{A}$, and $\mathrm{Na}^{+} / \mathrm{H}^{+}$antiporter from barley. J Exp Bot 55:585-594

114. Zahran HH et al (2007) Effect of salt stress on the expression of NHX-type ion transporters in Medicago intertexta and Melilotus indicus plants. Physiol Plant 131:122-130

115. Fukuda A et al (2004) Function, intracellular localization and the importance in salt tolerance of a vacuolar $\mathrm{Na}^{+} / \mathrm{H}^{+}$antiporter from rice. Plant Cell Physiol 45:146-159

116. Chen $\mathrm{H}$ et al (2007) Over-expression of a vacuolar $\mathrm{Na}^{+} / \mathrm{H}^{+}$antiporter gene improves salt tolerance in an upland rice. Mol Breed 19:215-225

117. Zhao F-Y et al (2006) Co-expression of the Suaeda salsa SsNHX1 and Arabidopsis AVP1 confer greater salt tolerance to transgenic rice than the single SsNHX1. Mol Breed 17:341-353

118. Xue Z-Y et al (2004) Enhanced salt tolerance of transgenic wheat (Tritivum aestivum L.) expressing a vacuolar $\mathrm{Na}^{+} / \mathrm{H}^{+}$antiporter gene with improved grain yields in saline soils in the field and a reduced level of leaf $\mathrm{Na}^{+}$. Plant Sci 167:849-859

119. Gaxiola RA et al (2001) Drought- and salt-tolerant plants result from overexpression of the AVP1 $\mathrm{H}^{+}$ -pump. Proc Natl Acad Sci U S A 98:11444-11449

120. Duan X-G et al (2007) Heterologous expression of vacuolar $\mathrm{H}^{+}$-PPase enhances the electrochemical gradient across the vacuolar membrane and improves tobacco cell salt tolerance. Protoplasma 232:87-95

121. Gao $\mathrm{F}$ et al (2006) Cloning of an $\mathrm{H}^{+}$-PPase gene from Thellungiella halophila and its heterologous expression to improve tobacco salt tolerance. J Exp Bot 57:3259-3270

122. Bao A-K et al (2009) Overexpression of the Arabidopsis H+-PPase enhanced resistance to salt and drought stress in transgenic alfalfa (Medicago sativa L.). Plant Sci 176:232-240
123. Li ZG et al (2010) Heterologous expression of Arabidopsis $\mathrm{H}^{+}$-pyrophosphatase enhances salt tolerance in transgenic creeping bentgrass (Agrostis stolonifera L.). Plant Cell Environ 33:272-289

124. Zhu J-K (2003) Regulation of ion homeostasis under salt stress. Curr Opin Plant Biol 6:441-445

125. Luan S (2009) The CBL-CIPK network in plant calcium signaling. Trends Plant Sci 14:37-42

126. Batistic O, Kudla J (2004) Integration and channeling of calcium signaling through the CBL calcium sensor/CIPK protein kinase network. Planta 219:915-924

127. Weinl S, Kudla J (2009) The CBL-CIPK $\mathrm{Ca}^{2+}$ decoding signaling network: function and perspectives. New Phytol 184:517-528

128. Wu SJ, Ding L, Zhu JK (1996) SOS1, a genetic locus essential for salt tolerance and potassium acquisition. Plant Cell 8:617-627

129. Qiu Q-S et al (2002) Regulation of SOS1, a plasma membrane $\mathrm{Na}^{+} / \mathrm{H}^{+}$exchanger in Arabidopsis thaliana, by SOS2 and SOS3. Proc Natl Acad Sci U S A 99:8436-8441

130. Qiu Q-S et al (2003) $\mathrm{Na}^{+} / \mathrm{H}^{+}$exchange activity in the plasma membrane of Arabidopsis. Plant Physiol 132:1041-1052

131. Vera-Estrella $R$ et al (2005) Salt stress in Thellungiella halophila activates $\mathrm{Na}^{+}$transport mechanisms required for salinity tolerance. Plant Physiol 139:1507-1517

132. Wu Y et al (2007) Molecular characterization of PeSOS1: the putative $\mathrm{Na}+/ \mathrm{H}+$ antiporter of Populus euphratica. Plant Mol Biol 65:1-11

133. Kolukisaoglu U et al (2004) Calcium sensors and their interacting protein kinases: genomics of the arabidopsis and rice CBL-CIPK signaling networks. Plant Physiol 134:43-58

134. Shi $\mathrm{H}$ et al (2003) Overexpression of a plasma membrane $\mathrm{Na}^{+} / \mathrm{H}^{+}$antiporter gene improves salt tolerance in Arabidopsis thaliana. Nat Biotechnol 21:81-85

135. Winicov I (2000) Alfin1 transcription factor overexpression enhances plant root growth under normal and saline conditions and improves salt tolerance in alfalfa. Planta 210:416-422

136. Cheong YH et al (2003) CBL1, a calcium sensor that differentially regulates salt, drought, and cold responses in Arabidopsis. Plant Cell 15:1833-1845

137. Tripathi V et al (2009) CIPK6, a CBL-interacting protein kinase is required for development and salt tolerance in plants. Plant J 58:778-790

138. Xiang Y, Huang YM, Xiong LZ (2007) Characterization of stress-responsive CIPK genes in rice for stress tolerance improvement. Plant Physiol 144:1416-1428

139. Zhao J et al (2009) Cloning and characterization of a novel CBL-interacting protein kinase from maize. Plant Mol Biol 69:661-674

140. Gisbert $C$ et al (2000) The yeast HAL1 gene improves salt tolerance of transgenic tomato. Plant Physiol 123:393-402 
141. Garciadeblás B et al (2003) Sodium transport and HKT transporters: the rice model. Plant J 34:788-801

142. Golldack D et al (2002) Characterization of a HKTtype transporter in rice as a general alkali cation transporter. Plant J 31:529-542

143. Horie T et al (2001) Two types of HKT transporters with different properties of $\mathrm{Na}^{+}$and $\mathrm{K}^{+}$transport in Oryza sativa. Plant J 27:129-138

144. Wang T-B et al (1998) Rapid up-regulation of HKT1, a high-affinity potassium transporter gene, in roots of barley and wheat following withdrawal of potassium. Plant Physiol 118:651-659

145. Horie $\mathrm{T}$ et al (2006) Calcium regulation of sodium hypersensitivities of $\operatorname{sos} 3$ and athkt1 mutants. Plant Cell Physiol 47:622-633

146. Maser $\mathrm{P}$ et al (2002) Altered shoot/root $\mathrm{Na}^{+}$distribution and bifurcating salt sensitivity in Arabidopsis by genetic disruption of the $\mathrm{Na}^{+}$transporter AtHKT1. FEBS Lett 531:157-161

147. Rus A et al (2006) Natural variants of AtHKT1 enhance $\mathrm{Na}^{+}$accumulation in two wild populations of Arabidopsis. PLoS Genet 2:1964-1973

148. Møller I et al (2009) Salinity tolerance engineered by cell type-specific over-expression of a $\mathrm{Na}^{+}$transporter in the Arabidopsis root. Plant Cell 21:2163-2178

149. Garg AK et al (2002) Trehalose accumulation in rice plants confers high tolerance levels to different abiotic stresses. Proc Natl Acad Sci U S A 99:15898-15903

150. Romero C et al (1997) Expression of the yeast trehalose-6-phosphate synthase gene in transgenic tobacco plants: pleiotropic phenotypes include drought tolerance. Planta 201:293-297

151. Negrāo S et al (2017) Evaluating physiological responses of plants to salinity stress. Ann Bot 119:1-11

152. Munns R et al (2016) Tissue tolerance: an essential but elusive trait for salt-tolerant crops. Funct Plant Biol 43:1103-1113

153. Saade $\mathrm{S}$ et al (2016) Yield-related salinity tolerance traits identified in a nested association mapping (NAM) population of wild barley. Sci Rep 6:32586

154. Munns R et al (2012) Wheat grain yield on saline soils is improved by an ancestral $\mathrm{Na}^{+}$transporter gene. Nat Biotechnol 30:360-364

155. James $R$ et al (2012) Impact of ancestral wheat sodium exclusion genes Naxl and Nax2 on grain yield of durum wheat on saline soils. Funct Plant Biol 39:609-618

156. Xu Y (2013) Functional characterization of wheat NHX antiporter gene TaNHX2 that encodes a $\mathrm{K}^{+} / \mathrm{H}^{+}$ exchanger. PLoS One 8(11):e78098

157. Feki $\mathrm{K}$ et al (2015) Comparative functional analysis of two wheat $\mathrm{Na}^{+} / \mathrm{H}^{+}$antiporter SOS1 promoters in Arabidopsis thaliana under various stress conditions. J Appl Genet 56:15-26

158. Olías R et al (2009) The plasmamembrane $\mathrm{Na}^{+} / \mathrm{H}^{+}$ antiporter SOS1 is essential for salt tolerance in tomato and affects the partitioning of $\mathrm{Na}^{+}$between plant organs. Plant Cell Environ 32:904-916

159. Byrt C et al (2018) Root cell wall solutions for crop plants in saline soils. Plant Science 269:47-55

160. Byrt CS et al (2014) The $\mathrm{Na}^{+}$transporter, TaHKT1;5$\mathrm{D}$, limits shoot $\mathrm{Na}^{+}$accumulation in bread wheat. Plant J 80:516-526

161. Julkowska M (2014) Capturing Arabidopsis Root Architecture Dynamics with root-fit Reveals Diversity in Responses to Salinity. Plant Physiology 166:1387-1402

162. Roy S et al (2013) Salt resistant crop plants. Curr Opin Biotechnol 26:115-124

163. Awlia M et al (2016) High-throughput non-destructive phenotyping of traits that contribute to salinity tolerance in Arabidopsis thaliana. Front Plant Sci 7:1414

164. Schmöckel S et al (2017) Identification of putative transmembrane proteins involved in salinity tolerance in Chenopodium quinoa by integrating physiological data, RNAseq, and SNP analyses. Front Plant Sci 8:1023

165. Zhao $\mathrm{Y}$ et al (2016) Hyperspectral imaging for determining pigment contents in cucumber leaves in response to angular leaf spot disease. Sci Rep 6:27790

166. Bassil et al (2014) The ins and outs of intracellular ion homeostasis: NHX-type cation $/ \mathrm{H}^{+}$transporters. Curr Opin Biotechnol 22:1-6

167. Julkowska M et al (2017) Genetic components of root architecture remodeling in response to salt stress. Plant Cell 29:3198-3213

168. Al-Tamimi $\mathrm{N}$ et al (2016) Salinity tolerance loci revealed in rice using high-throughput non-invasive phenotyping. Nat Commun 7:13342

169. Jarvis D et al (2017) The genome of Chenopodium quinoa. Nature 542:307

170. Mascher M et al (2017) A chromosome conformation capture ordered sequence of the barley genome. Nature 544:427

171. Zimin A et al (2017) The first near-complete assembly of the hexaploid bread wheat genome, Triticum aestivum. GigaScience 6:1-7

172. The Tomato Genome Consortium (2012) The tomato genome sequence provides insights into fleshy fruit evolution. Nature 485:635

173. Feng $\mathrm{W}$ et al (2018) The FERONIA receptor kinase maintains cell-wall integrity during salt stress through $\mathrm{Ca}^{2+}$ signaling. Curr Biol 28:1-10

174. Li B et al (2017) Chloride on the Move. Trends Plant Sci $22: 3$

175. Negrão S et al (2013) New allelic variants found in key rice salt-tolerance genes: an association study. Plant Biotechnol J 11:87-100

176. Geng Y et al (2013) A Spatio-temporal understanding of growth regulation during the salt stress response in Arabidopsis. Plant Cell 25:2132-2154 
177. Duan L et al (2013) Endodermal ABA signaling promotes lateral root quiescence during salt stress in Arabidopsis seedlings. Plant Cell 25:324-341

178. Julkowska M (2014) Capturing Arabidopsis root architecture dynamics with root-fit reveals diversity in responses to salinity. Plant Physiol 166:1387-1402

179. Barragan V et al (2012) Ion exchangers NHX1 and NHX2 mediate active potassium uptake into vacuoles to regulate cell turgor and stomatal function in Arabidopsis. Plant Cell 24:1127-1142

180. Tiwari S et al (2016) Mapping QTLs for salt tolerance in Rice (Oryza sativa L.) by bulked segregant analysis of recombinant inbred lines using 50K SNP Chip. PLoS One 11(4):e0153610

181. Tilbrook $J$ et al (2017) Variation in shoot tolerance mechanisms not related to ion toxicity in barley. Funct Plant Biol 44:1194-1206

182. Oyiga B et al (2018) Allelic variations and differential expressions detected at quantitative trait loci for salt stress tolerance in wheat. Plant Cell Environ 41:919-935

183. Riasat $\mathrm{M}$ et al (2018) Assessment of different wheat genotypes with altered genetic background in response to different salinity levels. J Plant Nutr 41:1821-1833

184. Mumtaz M et al (2018) Genotypic variation in rice for grain yield and quality as affected by salt-affected field conditions. J Plant Nutr 41:233-242

185. Watson A et al (2018) Speed breeding is a powerful tool to accelerate crop research and breeding. Nat Plants 4:23-29

186. Alahmad S et al (2018) Speed breeding for multiple quantitative traits in durum wheat. Plant Methods $14: 36$

187. Hickey L et al (2017) Speed breeding for multiple disease resistance in barley. Euphytica 2013:64

188. Gilliham $\mathrm{M}$ et al (2017) Translating knowledge about abiotic stress tolerance to breeding programmes. Plant J 90:898-917

189. Asif $M$ et al (2018) Mapping of novel salt tolerance QTL in an Excalibur $\times$ Kukri doubled haploid wheat population. Theor Appl Genet 131:2179-2196

190. Adem G et al (2014) Evaluating contribution of ionic, osmotic and oxidative stress components towards salinity tolerance in barley. BMC Plant Biol 14:113

191. Adem G et al (2015) Expressing AtNHX1 in barley (Hordeum vulgare L.) does not improve plant performance under saline conditions. Plant Growth Regul 77:289-297

192. Schilling $\mathrm{R}$ et al (2014) Expression of the Arabidopsis vacuolar $\mathrm{H}^{+}$-pyrophosphatase gene ( $A V P 1)$ improves the shoot biomass of transgenic barley and increases grain yield in a saline field. Plant Biotechnol J 12:378-386

193. Pasapula V et al (2011) Expression of an Arabidopsis vacuolar $\mathrm{H}^{+}$-pyrophosphatase gene $(A V P l)$ in cotton improves drought and salt tolerance and increases fibre yield in the field conditions. Plant Biotechnol J 9:88-99

194. Schilling R et al (2017) AVP1: one protein, many roles. Trends Plant Sci 22:2

195. Sathee L et al (2015) Differential transcript abundance of salt overly sensitive (SOS) pathway genes is a determinant of salinity stress tolerance of wheat. Acta Physiol Plant 37:169

196. Li B et al (2016) Identification of a stelar-localized transport protein that facilitates root-to-shoot transfer of chloride in Arabidopsis. Plant Physiol 170:1014-1029

197. Mahfouz M (2014) Genome engineering via TALENs and CRISPR/Cas9 systems: challenges and perspectives. Plant Biotechnol J 12:1006-1014

198. Li T et al (2018) Domestication of wild tomato is accelerated by genome editing. Nat Biotechnol 36:1160-1163

199. Almeida D et al (2017) Regulation of $\mathrm{Na}^{+}$and $\mathrm{K}^{+}$ homeostasis in plants: towards improved salt stress tolerance in crop plants. Genet Mol Biol 40:326-345

200. Mian A et al (2011) Over-expression of an $\mathrm{Na}^{+}$- and $\mathrm{K}^{+}$-permeable HKT transporter in barley improves salt tolerance. Plant J 68:468-479

201. Amin A, Diab A (2013) QTL mapping of wheat (Triticum Aestivum L.) in response to salt stress. Int J Biotechnol 3:47-60

202. Azadi A et al (2015) QTL mapping of yield and yield components under normal and salt-stress conditions in bread wheat (Triticum aestivum L.). Plant Mol Biol Report 33:102-120

203. León J (2011) Quantitative trait loci associated with salinity tolerance in field grown bread wheat. Euphytica 181:371-383

204. Genc Y et al (2013) Quantitative trait loci for agronomic and physiological traits for a bread wheat population grown in environments with a range of salinity levels. Mol Breed 32:39-59

205. Genc Y et al (2010) Sodium exclusion QTL associated with improved seedling growth in bread wheat under salinity stress. Theor Appl Genet 121:877-894

206. Genc Y et al (2014) A major locus for chloride accumulation on chromosome $5 \mathrm{~A}$ in bread wheat. PLoS One 9:e98845

207. Ghaedrahmati M et al (2014) Mapping QTLs associated with salt tolerance related traits in wheat (Triticum aestivum L.). J Agric Sci Technol 16:1413-1428

208. Ahmadi-Ochtapeh $\mathrm{H}$ et al (2015) QTL mapping for salt tolerance in barley at seedling growth stage. Biol Plant 59:283-290

209. Gill M et al (2017) Cell-based phenotyping reveals QTL for membrane potential maintenance associated with hypoxia and salinity stress tolerance in barley. Front Plant Sci 8:1941 
210. Liu X et al (2017) QTLs for stomatal and photosynthetic traits related to salinity tolerance in barley. BMC Genomics 18:9

211. Dura S et al (2014) Detection of molecular markers associated with yield and yield components in durum wheat (Triticum turgidum L. var. durum) under saline conditions. Crop Pasture Sci 64:957-964

212. Shamaya $\mathrm{N}$ et al (2017) Genetics of $\mathrm{Na}^{+}$exclusion and salinity tolerance in Afghani durum wheat landraces. BMC Plant Biol 17:209

213. Turki N et al (2015) Detection of QTLs associated with salinity tolerance in durum wheat based on association analysis. Euphytica 201:29-41

214. Xue W et al (2017) A major QTL on chromosome 7HS controls the response of barley seedling to salt stress in the Nure $\times$ Tremois population. BMC Genet 18:79

215. Roy S et al (2013) A novel protein kinase involved in $\mathrm{Na}^{+}$exclusion revealed from positional cloning. Plant Cell Environ 36:553-568

216. Li D et al (2012) Two CBL genes from Poplus euohratica confer multiple stress tolerance in transgenic triploid white poplar. Plant Cell Tissue Organ Cult 109:477-489

217. Thoday-Kennedy E et al (2015) The role of the CBLCIPK calcium signaling network in refulating ion transport in response to abiotic stress. Plant Growth Regul 76:3-12 